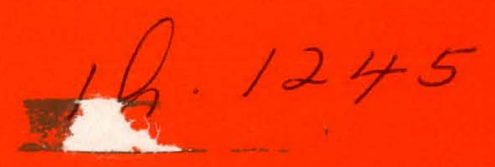

\title{
The National Energy Act Statutes and Solar Energy
}

\section{MASTER}

Judy Howard
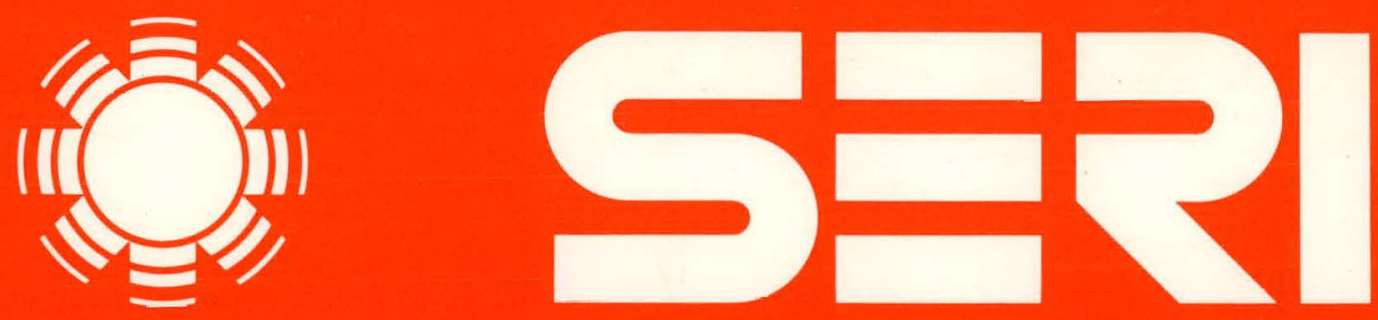

Solar Energy Research Institute

A Division of Midwest Research Institute

1617 Cole Boulevard

Golden, Colorado 80401

Operated for the

U.S. Department of Energy under Contract No. EG-77-C-01-4042 


\section{DISCLAIMER}

This report was prepared as an account of work sponsored by an agency of the United States Government. Neither the United States Government nor any agency Thereof, nor any of their employees, makes any warranty, express or implied, or assumes any legal liability or responsibility for the accuracy, completeness, or usefulness of any information, apparatus, product, or process disclosed, or represents that its use would not infringe privately owned rights. Reference herein to any specific commercial product, process, or service by trade name, trademark, manufacturer, or otherwise does not necessarily constitute or imply its endorsement, recommendation, or favoring by the United States Government or any agency thereof. The views and opinions of authors expressed herein do not necessarily state or reflect those of the United States Government or any agency thereof. 


\section{DISCLAIMER}

Portions of this document may be illegible in electronic image products. Images are produced from the best available original document. 
Printed in the United States of America Available from:

National Technical Information Service

U.S. Department of Commerce

5285 Port Royal Road

Springfield, VA 22161

Price:

\section{Microfiche $\$ 3.00$}

Printed Copy $\$ 5.25$

\section{NOTICE}

This report was prepared as an account of work sponsored by the United States Government. Neither the United States nor the United States Department of Energy, nor any of their employees, nor any of their contractors, subcontractors, or their employees, makes any warranty, express or implied, or assumes any legal liability or responsibility for the accuracy, completeness or usefulness of any information, apparatus, product or process disclosed, or represents that its use would not infringe privately owned rights. 


\section{SERI /TR-434-424 \\ UC CATEGORY: UC-58}

THE NATIONAL ENERGY ACT

STATUTES AND SOLAR

ENERGY

JUDY HOWARD

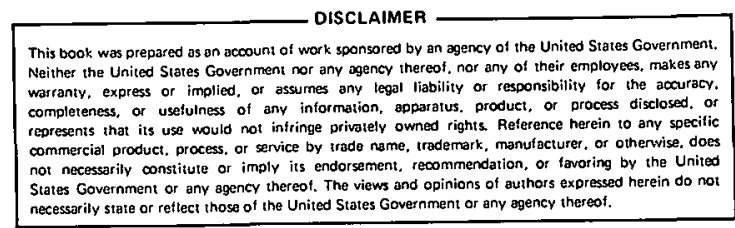

FEBRUARY 1980

PREPARED UNDER TASK NO. 6721.40

\section{Solar Energy Research Institute}

\section{Cole Boulevard \\ Golden, Colorado 80401}

\section{A Division of Midwest Research Institute}

Prepared for the

U.S. Department of Energy

Contract No. EG $\cdot 77 \cdot C \cdot 01 \cdot 4042$ 
THIS PAGE

\section{WAS INTENTIONALLY LEFT BLANK}


FOREWORD

This report on the solar aspects of the National Energy Act statutes of 1978- was prepared by the Solar Energy Research Institute to fulfill, in part, SERI's solar information dissemination function. The report is part of the Community and Consumer Branch Law Program, which in turn is a part of the overall program of the Planning Applications and Impacts Division.

This report was written to survey the statutes of the 1978 National Energy Act in order to better understand how these statutes impact the future development of solar energy. The statutes of the 1978 National Energy Act are among the most significant federal initiatives addressing the conditions of solar development.

The author of this report, Judy Howard, is a law student at the University of Colorado School of Law. She was a law clerk to the Law Program during the summer of 1979. The Law Program is under the general supervision of Jan G. Laitos, SERI Senior Legal Specialist.
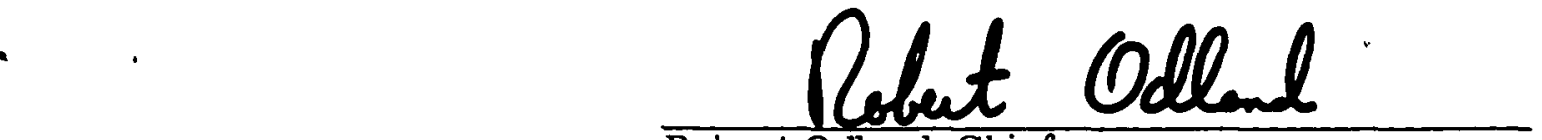

Robert Odland, Chief

$\cdot$

Community and Consumer Branch

Approved for:

SOLAR ENERGY RESEARCH INSTITUTE

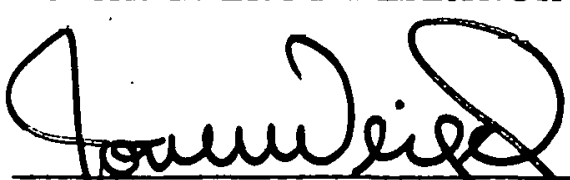

Jon M. Veigel, Division Manager

Planning Applications and Impacts Division 
THIS PAGE

\section{WAS INTENTIONALLY LEFT BLANK}




\section{SUMMARY}

The National Energy Act of 1978 contains provisions that are very important to the commercialization of solar technologies. The provisions will result in greater public knowledge about the practicality of and energy savings available from solar technologies. They will encourage installation of solar devices in homes, in public and commercial buildings, and in industrial applications through various financial incentives. They will also improve the economic competitiveness of solar energy technologies through voluntary utility rate structure changes and mandatory interconnections with certain small power producers.

The act contains five statutes aimed at decreasing our dependence on foreign sources of energy by encouraging energy conservation and domestic energy production. Each statute focuses on a particular aspect of our energy problem.

The National Energy Conservation Policy Act promotes more efficient use of nonrenewable energy sources and increased utilization of renewable energy sources. It establishes a program, to be implemented by utilities and home heating suppliers nationwide, that will greatly increase the information and assistance available to homeowners interested in installing conservation and solar energy equipment. It also provides for programs that will increase the number of solar equipment installations in public buildings and will utilize federal buildings to demonstrate solar energy technology. This statute also provides for substantial federal photovoltaics purchases, designed to bring the costs of photovoltaics to a level that allows competition with other energy source applications.

The Energy Tax Act provides for tax credits for homeowners and businesses (including industrial users) that purchase and install certain types of solar technologies.

The Public Utilities Regulatory Policies Act outlines various rate structures to be used by utilities that will not discourage the use of solar energy. It also mandates that small energy producers (such as facilities that use biomass, wind, sun, or hydro) be allowed to connect with transmission lines of utilities. Such connections will permit the small producers to obtain electricity from the utility when needed and to sell any of their own electricity that they may not need. The Act is intended to encourage prices for electricity that are fair and equitable for both parties, whether buying or selling electricity.

The Powerplant and Industrial Fuel Use Act prohibits the burning of natural gas or oil by utilities and large fuel burning facilities except under specified conditions. Some of the specified conditions will encourage research and use of solar energy by large fuel consumers. For instance, utilities and major fuel burning installations may burn some gas if they combine it with an "alternate fuel." Alternate fuels are fuels other than oil and gas, including coal and solar energy. The availability of this option may result in more use of solar energy by large fuel burners.

The Natural Gas Policy Act will have only an indirect effect on solar technology commercialization, and will not be discussed in this report.

The four statutes that have been described above are discussed in this report, and their possible effects on solar energy technologies are identified. Their limitations, in terms of promoting solar technology, are also noted. 
THIS PAGE

\section{WAS INTENTIONALLY LEFT BLANK}




\section{TABLE OP CONTENTS}

Page

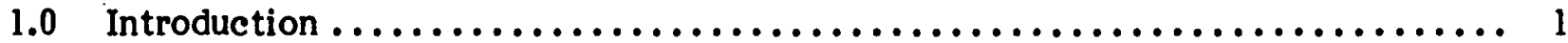

1.1 Legislative History $\ldots \ldots \ldots \ldots \ldots \ldots \ldots \ldots \ldots \ldots \ldots \ldots \ldots \ldots \ldots \ldots \ldots \ldots$

1.2 The Role of the Five Acts in Achieving Congressional Goals........... 1

2.0 The National Energy Conservation Policy Act ..................... 5

2.1 The Residential Conservation Service Programs ................ 5

2.2 Weatherization Grants .............................. 8

2.3 Loans and Loan Insurance for Solar Installations .................. 8

2.4 Solar Equipment Installations in Public Housing ................. 9

2.5 Mandatory Energy Efficiency Standards ..................... 9

2.6 Conservation Programs for Schools, Hospitals, and Local Government and Public Care Buildings ................................ 10

2.6.1 School and Hospital Conservation Programs ................. 11

2.6.2 Conservation Programs for Buildings Owned by Units of Local

Government and Public Care Institutions ................ 12

2.7 Federal Purchase and Demonstration Program ................. 13

2.7.1 Federal Demonstration Program..................... 13

2.7.2 Space Heating and Cooling Demonstration Project ........... 13

2.7.3 Solar Energy System Use in Federal Buildings ................ 14

2.7.4 The Federal Photovoltaic Utilization Program.............. 14

2.7.5 The Secretary of Energy's Duties ..................... 15

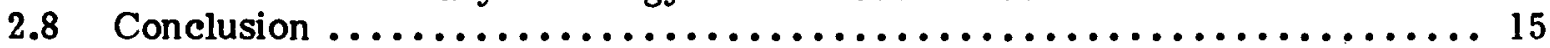

3.0 The Energy $\operatorname{Tax}$ Act $\ldots \ldots \ldots \ldots \ldots \ldots \ldots \ldots \ldots \ldots \ldots \ldots \ldots \ldots \ldots$

3.1 Introduction $\ldots \ldots \ldots \ldots \ldots \ldots \ldots \ldots \ldots \ldots \ldots \ldots \ldots \ldots \ldots \ldots \ldots \ldots \ldots$

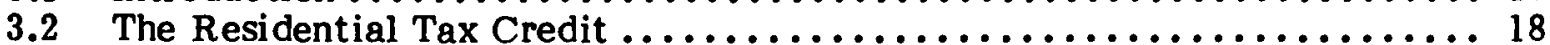

3.3 The Business Investment Credit $\ldots \ldots \ldots \ldots \ldots \ldots \ldots \ldots \ldots \ldots \ldots \ldots \ldots \ldots \ldots 2$

3.4 Conclusion ...................................... 25

4.0 The Public Utility Regulatory Policies Act..................... 27

4.1 Electric Utility Retail Policies ......................... 28

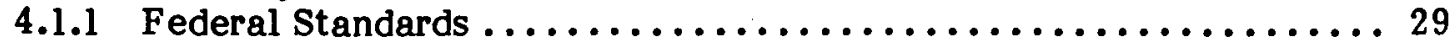

4.1.2 Electric Utility Information Requirements ............... 30

4.2 Interconnection, Pooling, Cogeneration, and Small Power

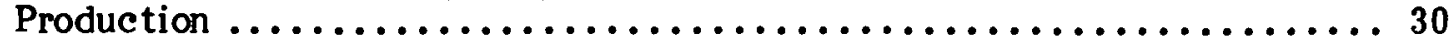

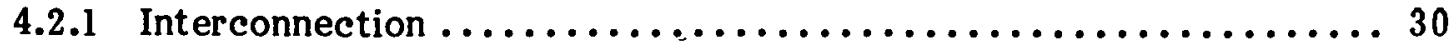

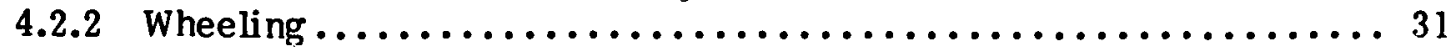

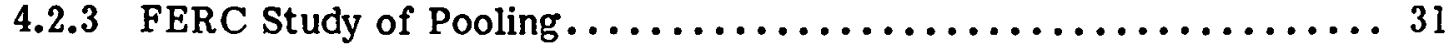

4.2.4 Cogeneration and Small Power Production ................ 32

4.2.5 Exemptions for Certain Hydroelectric Facilities ............. 32

4.3. Natural Gas Utility Retail Policies ....................... 32

4.3.1 Federal Standards .............................. 32

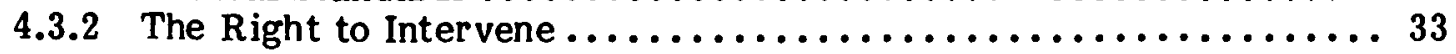

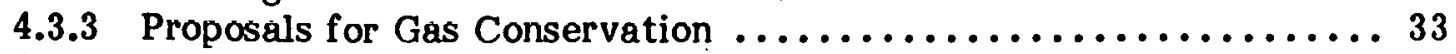

4.3.4 The Secretary's Report......................... 33 
TABLE OF CONTENTS (continued)

Page

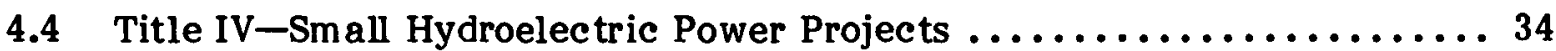

4.4.1 The DOE Program .............................. 34

4.4.2 Simpler Licensing Process for Hydroelectric Projects .......... 34

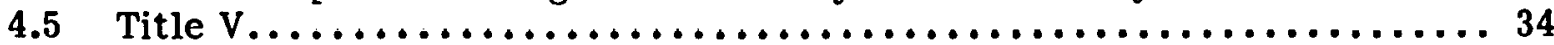

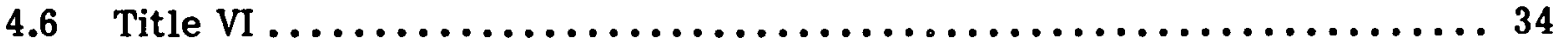

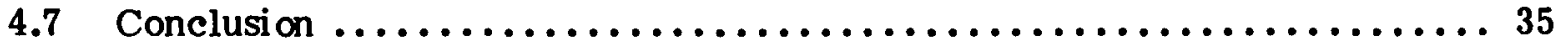

5.0 The Powerplant and Industrial Fuel Use Act....................... 37

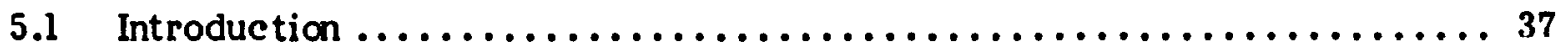

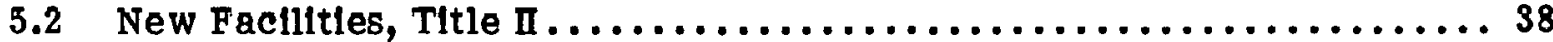

5.2.1 New Electric Power Plant Prohibitions ................... 38

5.2.2 New Major Fuel Burning Installation Prohibitions $\ldots \ldots \ldots, \ldots, \ldots, 41$

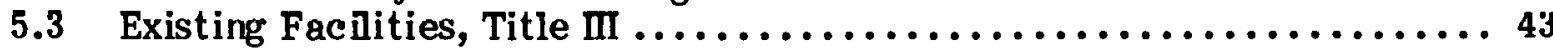

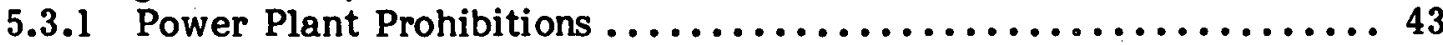

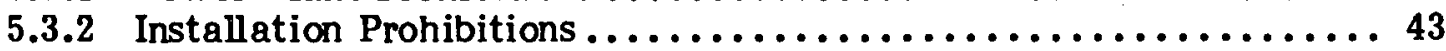

5.3.3 Temporary Exemptions..............................43

5.3.4 Permanent Exemptions.............................. 44

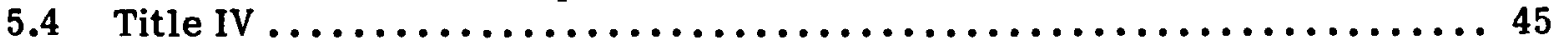

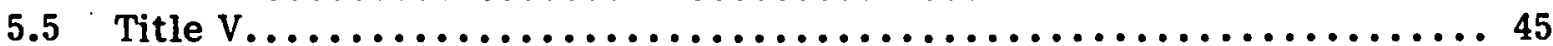

$5.6 \quad$ Title VI ............................................... 45

$5.7 \quad$ Title VII .............................................. 46

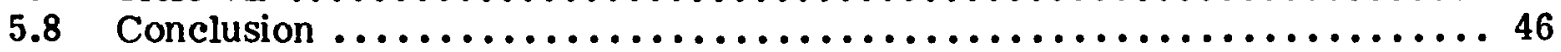

6.0 The Natural Gas Policy Act of $1978 \ldots \ldots \ldots \ldots \ldots \ldots \ldots \ldots \ldots \ldots \ldots \ldots$

7.0 Conclusion.$\ldots \ldots \ldots \ldots \ldots \ldots \ldots \ldots \ldots \ldots \ldots \ldots \ldots \ldots \ldots \ldots \ldots \ldots \ldots$

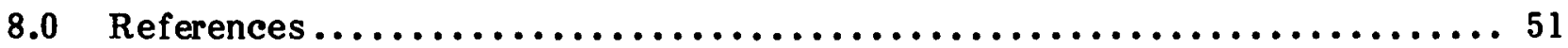




\section{SECTION 1.0}

\section{INTRODUCTION}

This report identifies those statutes of the National Energy Act (NEA) that are likely to have a significant effect on the commercialization of solar technologies or on solar energy system users. Four of the five statutes that make up the NEA will be treated separately in the body of this report. The National Gas Policy Act [1] will not be analyzed in detail because its provisions should have only an indirect effect on solar energy technologies.

\subsection{LEGISLATTVE HISTORY}

Congress passed the National Energy Act (NEA) statutes on 9 Nov. 78 [2]. The implementation of the five statutes included in the NEA [3] was intended to allow the U.S. economy to make a smooth transition into an age of high energy prices [4]. The NEA is designed to achieve three major ends: promotion of energy conservation, conversion to coal and renewable energy sources, and incentives to encourage domestic energy production [5].

\subsection{THE ROLE OP THE FIVE ACTS IN ACHIEVING CONGRESSIONAL GOALS}

Each of the five acts is designed to play a unique role in bringing about Congress' proclaimed ends.

The National Energy Conservation Policy Act (NECPA) will play a major role in energy conservation. NECPA declares that every state must promulgate a plan, to be approved by the Secretary of Energy, that outlines how that state will comply with NECPA's requirements. The most important part of each state plan will probably be prescribed procedures for the implementation of utility programs.

Electric and natural gas utilities must send out program announcements informing their residential customers about practices and devices that are likely to result in home energy savings [6]. These devices have been recommended by the Department of Energy (DOE) for the utility's climatic region. Such devices are called "suggested measures" and are either energy conservation or renewable resource consuming devices that DOE has determined cost less, or only as much as, the residential customer would have paid for energy had the devices not been installed. Among the suggested measures for most areas of the country are solar domestic water heaters. Wind energy conversion systems (WECS) are suggested measures in areas with high average wind speeds and high electric utility rates. Most of the residences in the United States will receive a program announcement containing information on the energy saving potential of solar energy systems that have been designated as suggested measures.

Utilities must perform an "energy audit" for any residential customer who requests one and has not already had one. An energy audit is an on-site survey of the energy saving potential of practices, such as setting a lower temperature on water heaters or thermostats, and suggested measures. The energy audit will inform homeowners of which suggested measures would be best in terms of costs and savings for their particular homes. In some cases, the auditors will recommend solar energy devices. If an expert 
recommends such devices after inspecting a home, some homeowner doubts about the appropriateness of solar energy systems should be allayed. Homeowners are more likely to install solar energy devices once assured that such a device will be more economical than expensive.

Utilities must provide two additional services to any residential customer who requests them. They must supply their customers with a list of sellers and installers of suggested measures who operate within the utility's service areas, and they must arrange for installation of any suggested measure that a customer requests [7]. In order to qualify for inclusion on the list, sellers' products must carry the 3-yr program warranty, and installers' products must be warranted and comply with all applicable state plan requirements. The lists must also include the names of financial institutions that offer loans for persons wishing to purchase and install suggested measures. With a list of suppliers, installers, and lenders, the process of converting to solar energy devices will be less worrisome for the hom eowner. Hom eowners who resisted solar device installation because the investigation of equipment sources, services, and financing seemed too time consuming may take advantage of the lists and install solar devices. It is difficult to estimate the number of homeowners that will act as a result of the list requirement, but it could be significant. Residential solar energy devices have not been widely available, and many homeowners may be apprehensive of dealing with unfamiliar products, merchants, and contractors. The homeowner should feel more confident about solar device, merchant, and installer reliability if he realizes that certain minimum standards have been met by those included in the list. Consumers who take advantage of the utility lists will probably buy adequate products and hire competent installers, resulting in solar commercialization promotion and establishment of a good reputation for the solar energy industry.

Utilities must arrange the financing and installation of any suggested measure requested by a customer. Each state determines the conditions of the arrangement [8]; however, utilities must not simply distribute the lists of qualified suppliers, installers, and lending institutions [9]. This service should lead to increased residential solar equipment instillations by making them less troublesome for the homeowner. Those interested in solar devices who felt that having one installed would be too time consuming may take advantage of the utility's service. The number of residential solar energy systems installed will increase, and solar technology commercialization will be stimulated.

To further promote residential energy conservation, NECPA provides a loan guarantee program and a low interest loan program to assist citizens wishing to install solar energy systems or other energy conservation measures [10]. Both programs will increase the amount of money available to finance solar energy system installations and benefit solar commercialization.

The utility program mandated by NECPA removes most obstacles to faster solar device commercialization. The public will be informed about the availability and the technical and economic feasibility of solar devices. Adequate quality of products and contractor service will be guaranteed, and money will be available to finance installation of solar devices. The solar industry must supply an adequate number of reliable systems to take full advantage of the demand created by utility programs.

Public and nonprofit schools and hospitals, units of local government, and public care institutions are eligible for assistance with solar energy system installation [11]. Schools and hospitals may receive financing, while public care institutions and units of local government may receive assistance in determining which types of energy saving measures would be appropriate for their buildings. NECPA mandates federal purchases of a 
variety of solar energy systems, as well as a solar energy system demonstration program using federal buildings [12]. The federal purchase and demonstration programs will increase solar industry sales and provide an avenue of consumer education.

The Energy Tax Act (ETA) provides for residential and commercial tax credits designed to encourage widespread installation of energy conserving equipment, including solar energy systems [13].

Homeowners are eligible for an income tax credit of $30 \%$ of the first $\$ 2,000$ and $20 \%$ of the next $\$ 8,000$ spent for qualifying solar equipment. New equipment expected to operate for at least five years that transmits or uses solar energy, or any other form of renewable energy that the Secretary of the Treasury specifies by rule published in the Federal Register, to heat, cool, or provide hot water to a dwelling, qualifies for the residential tax credit. WECS providing wind energy to residences for nonbusiness purposes also qualify. The very existence of the credit, if it becomes widely known, will lead a significant number of hom eowners to investigate the solar system market. This credit will reduce the initial cost of qualifying solar systems for homeowners. A lower cost will make solar heating and cooling (SHAC) systems more competitive with conventional heating and cooling systems. As a result, more SHAC systems should be installed.

Businesses are eligible for a $10 \%$ energy investment tax credit. This credit is available in addition to the regular $10 \%$ investment tax credit available for qualifying capital expenditures. However, solar energy property that is a structural component of a building probably cannot qualify for a $20 \%$ credit, because structural components of buildings generally do not qualify for the regular investment credit. The business credit will benefit solar commercialization, but has been criticized as being too small to have a substantial effect. The 1982 expiration date for the credit has also been accused of being too premature to benefit industrial users. Many companies may be unable or unwilling to take advantage of the credit before it expires.

The Public Utilities Regulatory Policies Act (PURPA) will promote energy conservation through the reformation of electricity and natural gas utility rate structures so that they reflect the true cost of providing service to each class of consumer [14]. If utility customers have paid less for their service than it actually cost, rate structure reformations should result in customer efforts to reduce their energy demand. This will simply be a matter of conserving energy through greater efficiency; however, utility customers may install solar energy systems to meet their energy needs at acceptable costs.

PURPA also sets out voluntary rate standards for electric and gas utilities [15] that may reduce a utility's new facility requirements. Solar technologies and solar system users would benefit from lower utility capital costs, because the capital cost component of utility rates would be reduced. With a smaller capital cost component, and thereby a larger energy cost component, solar energy system users would pay significantly less for their utility service than customers who relied entirely on utility power. As fossil fuel costs continue to rise and utility bills increase accordingly, there will be an even greater incentive to convert to solar energy systems. The solar industries can expect increasing demand, which they may facilitate by reducing their production costs and prices, making their products more competitive.

PURPA establishes a loan program to finance the construction of hydroelectric facilities at existing dams [16]. The program will benefit hydroelectric industries and may help other solar industries by making their products more economically feasible. For 
example, a solar energy system could be used to pump water up behind a dam. If a hydroelectric generator installed as a result of the loan program could convert that stored water into electricity, the solar energy system would supply more usable energy. This additional energy may determine the cost-effectiveness of a solar energy system.

The Powerplant and Industrial Fuel Use Act (PIFUA) severely restricts the use of petroleum or natural gas by electric utilities and major fuel-burning installations [17]. By doing so, it will force power plants and major installations to rely on other primary energy sources in the future. Solar thermal systems will probably supply energy for an increasing number of boilers. Methane gas, produced from feedlot manure and municipal solid waste, may be the primary energy source for additional power plants.

PIFUA includes numerous exemptions from restrictions on the use of petroleum and natural gas. Some of the exemptions should have a substantial positive effect on power plant and industrial conversion to solar technologies. For instance, new power plants and installations may receive temporary prohibition exemptions if their owners establish that their facilities will adopt an innovative technology for the use of an alternate fuel (i.e., other than petroleum, natural gas, or coal) upon expiration of the exemption. Such an exemption will allow facility designers additional time to explore new ways of using solar energy as the primary energy source. With more time to study solar energy systems, additional economic designs may be devised. Plant operators who could not choose solar energy as their primary energy source, given current system costs, may take advantage of the temporary exemption to develop a more competitively priced solar energy design. This would benefit solar technologies in two ways. First, the number of solarpowered facilities would be increased. Facilities that could not operate economically on solar energy would be able to later convert to solar technology. Second, more costcompetitive designs would be available as a result of the additional time spent in experimenting with new technologies.

The Natural Gas Policy Act (NGPA) is designed to encourage domestic natural gas production and discourage natural gas consumption [18]. The act will raise natural gas prices and make other energy sources more economically feasible. Solar energy technology will benefit from NGPA's mandates because natural gas consumers will rely on some form of solar energy instead of gas. 


\section{SECTION 2.0}

\section{THE NATIONAL ENERGY CONSERVATION POLICY ACT}

NECPA is one of the five statutes included in the NEA. It was intended to slow the growth of energy consumption in the United States and to conserve nonrenewable energy resources [19]. Because of the residential conservation service (RCS) programs that it mandates, it may well increase the rate of solar technology commercialization more than any of the other acts.

Title II of NECPA mandates RCS programs that are intended to result in residential energy conservation. Every state must promulgate a plan, subject to approval by the Secretary of Energy, that will set the requirements for utility [20] RCS programs. DOE has prescribed certain plan requirements, but has chosen to give the state a great deal of flexibility in designing plans suitable for their areas [21]. The state plans must specify appropriate energy-saving devices, practices, and utility services offered to customers. The energy-saving devices are called suggested measures. They are devices that DOE has determined will save more in energy costs than their purchase and installation price [22]. Their operation must be warranted for three years and they must be commercially available [23]. Suggested measures vary by climatic region and the type of fuel burned in a building. Domestic water heaters, active space heating systems, a system that heats both space and water, passive SHACS, WECS, and replacement solar swimming pool heaters are suggested measures in various parts of the country [24].

Title III of NECPA covers energy conservation in schools, hospitals, buildings owned by units of local government, and public care institutions. It authorizes the allocation of funds to the states. These funds are distributed to public or nonprofit schools and hospitals for the purpose of affecting practices or installing systems that will significantly reduce the nonrenewable energy consumption in their buildings. Public care institutions and units of local government are eligible for funding to conduct investigations of the energy saving potential of various practices or measures, but they may not receive funds to finance the purchase and installation of energy saving devices under NECPA.

Title IV deals with energy efficiencies in motor vehicles and appliances and does not affect solar technology.

Title $\mathrm{V}$ authorizes a nationwide solar technology demonstration project, the installation of solar systems in federal buildings, and a Federal Photovoltaic Utilization Program (FPUP). All three programs should help the solar industry in a number of ways. First, the amount of funds authorized for these programs is substantial and should affect largescale low-cost production methods. Second, all three programs will serve to demonstrate the availability and practicability of solar energy systems. Finally, the federal programs should produce useful data on the functioning and problems of solar systems.

\subsection{THE RESIDENTIAL CONSERVATION SERVICE PROGRAMS}

The governor or utility-regulating agency of each state and most nonregulated utilities must submit a plan to the Secretary of Energy for approval. 
The state plan and nonregulated utility plans should benefit the commercialization of solar technology by establishing the requirements of utility and home heating supplier programs. If a state has not submitted an acceptable plan or has not implemented an approved plan satisfactorily, the Secretary of Energy must provide that state with a plan [25]. Every nonregulated utility that is not covered by an approved state plan or does not have a satisfactorily implemented approved plan is subject to the Secretary's order to promulgate an acceptable plan and offer its residential customers a utility program within 90 days of the order [26]. Within a year, every state and nonregulated utility will have a plan. The plans will result in the energy consuming public being provided with information on the energy saving potential of solar energy devices. The dissemination of that information and the availability of services that utilities must offer their customers should lead to larger residential solar energy device sales in areas in which solar energy systems are cost competitive. The additional sales will be to consumers who were not aware of the immediate availability and practicality of solar energy systems. Another important aspect of the state plans will be DOE product and labor standards that will be imposed on sellers and installers of solar devices. Such standards should result in unif orm work and products, and widespread consumer satisfaction that will benefit solar technology commercialization.

Every state plan must contain procedures for investigation and enforcement of utility compliance with NECPA's mandates. The Secretary of Energy will not approve a state plan unless he is satisfied that its enforcement mechanisms are both adequate and practicable [27], and cannot approve a plan that does not require that the utilities [28] send program announce ments to their residential customers. Home heating suppliers may participate in RCS programs, and the governor may waive any program requirement that would be financially burdensome because of the small size of a particular home heating supplier. The program announcements must explain the energy savings likely to result from installation of each solar energy system that DOE has designated as a suggested measure for the utility's service area [29]. They must also inform customers of the following services that each utility must offer its residential customers:

- energy audits (i.e., inspection of the customer's home followed by a report of all the auditor's recommendations of energy conserving practices and measures, along with an estimate of the cost and energy saving capacity of each);

- provision of a list (drawn from the state's master record) of qualified sellers and installers of suggested solar energy systems, as well as lending institutions that will finance the purchase and installation of such systems in the utility's service area; and

- utility arrangements for installation and financing of suggested measures that are requested by eligible customers. Each state must develop an arrangement suitable to its region, which consists of more than the mere distribution of lists $[30]$.

Utilities may be exempted from certain prohibitions; i.e., supplying, installing, or financing suggested measures. The state plan must contain a procedural guide for such utilities and the list of qualifiers [31]. These procedures should:

- designate an agency responsible for preparing such a list (hereafter called a Master Record),

- notify suppliers, installers, and lending institutions for suggested measures about the creation of the Master Record, and

- ensure that all qualified persons are included in the Record [32] . 
In order to qualify for inclusion on the list, sellers must supply products that meet DOE standards [33]. Solar domestic water heater and active space heating systems must comply with HUD intermediate minimum property standards [34]. The standards for thermosiphon hot water heater, passive SHACS, and solar swimming pool heaters will be prescribed in the future [35]. The proposed wind system requirements and siting requirements have been published [36]. Installers' devices must comply with the preceding standards and be covered by the 3-yr program warranty. Installers must give program customers a written contract specifying the work to be performed, its price, and guaranteeing their compliance with all applicable state plan requirements. They must guarantee free replacement or repair of any part of the system that does not meet the program standards. In the case of defective WECS, installers must guarantee repair or replacement as soon as possible after the installer has been notified of the problem. Finally, installers must submit copies of all contracts for installation of suggested measures to the customer's utility or home heating supplier [37], and must agree to participate in any complaint proceeding brought by the customer against the installer [38]. Lending institutions are eligible for inclusion on the list if they agree to follow the prescribed method for resolving billing error disputes [39]. They must also agree not to accept the homeowner's principal residence as security for the loan unless the homeowner provides written acknowledgement of his or her awareness of the consequences of default on the loan [40]. Lending institutions must also permit rebates of unearned finance charges [41].

State plans must define the following utility customer benefits:

- a program warranty that the customer's suggested measure will have a useful life of at least three years,

- a guarantee that all program materials, installation standards, and listing requirem ents have been met,

- inclusion in the pool from which suggested measure installations are randomly selected for inspection, and

- access to an informal conciliation conference whenever the customer believes that he has sustained some loss because of a plan violation [42].

The RCS programs should have a major effect on solar technology commercialization. Because of the information and services that utilities and home heating suppliers must provide under the programs, there should be a substantial increase in the number of residential solar energy system installations. Hom eowners who had not considered such solar devices practical will be encouraged and interested by this information. Because commercial cost-competitive solar energy systems have not been widely available, many homeowners probably think solar energy heated homes and water are things of the future. The program announcements and energy audits should dispel many doubts about the immediate practicality of solar energy systems and former skeptics may install a solar device.

Some will decide to install such systems as a result of the services that the utilities must supply, and some will use the lists to solicit bids for the installation of solar devices or investigate the terms offered by various lending institutions. The list should make the selection of a supplier, installer, or lender less time consuming and uncertain. The utility arrangements, while they will vary from plan to plan, should make the homeowner's selection process even easier. The less burdensome the procedure appears to be, the more homeowners should be willing to have solar energy devices installed. In order to maximize the benefits that can be derived from the increased demand created by RCS 
programs, solar industries must maintain the quality of their products while increasing their production volume.

The lists will benefit solar technology commercialization in terms of quality standards. Because of the requirements for inclusion on a list, consumers who rely on the lists or utility arrangements are very likely to receive reliable products and competent installations. Public acceptance of solar industries will increase if their products and workmanship are satisfactory. Also, the lists provide a form of free advertising. They must supply only the most basic information (names, addresses, and suggested measures supplied, installed, or financed) and must avoid giving unfair advantage to any listed parties [43]. For small companies, inclusion on the lists and subsequent reduction of advertising costs could be an appreciable financial benefit.

\subsection{WEATHERIZATION GRANTS}

Part 2 of Title II of NECPA deals with weatherization grants and does not concern solar technology comm ercialization.

\subsection{LOANS AND LOAN INSURANCE POR SOLAR INSTALLATIONS}

Part 3 covers secondary financing and loan insurance for solar energy systems. The Department of Housing and Urban Development (HUD) must administer amended provisions of the Federal National Mortgage Association Charter Act (FNMACA) [44], the Federal Home Loan Mortgage Corporation Act (FHLMCA) [45], and the National Housing Act (NHA) [46], which authorize loans, loan insurance, and credit advances to eligible persons for the purpose of financing and insuring residential solar energy system installations. The Government National Mortage Association (GNMA) is authorized to purchase solar energy system loans by an amendment of FNMACA [47]. The GNMA may buy, service, and sell loans and credit advances to the owners of one- to four-unit residences for the purpose of purchasing or installing solar energy systems [48]. If less than 50\% of the funds authorized for such purposes (which may be up to $\$ 100$ million) have been used after a year, the Secretary of HUD must set the interest rate of its loans and credit advances at the lowest permissible level [49]. This authorization will make moderate interest loans available to people wishing to install solar devices. The availability of such loans should increase the rate of solar installations by people who were interested in solar energy systems but felt that the available interest rates were unacceptable. The number of extra installations resulting from this amendment will depend on how many homeowners have been deterred by high interest rates, as well as the interest rate at which GNMA loans and credit advances are offered.

Part 3 also amends FHLMCA [50] by expanding the definition of "residential mortgage." Loans and credit advances for financing the purchase and installation of residential solar energy systems are now defined as residential mortgages [51]. This addition makes solar energy system mortgages eligible for FHLMCA purchasing, servicing, or selling [52].

The Secretary of HUD may insure loans for the purchase or installation of solar energy systems in multifamily housing projects [53]. This NHA amendment should increase the availability of financing for multifamily-dwelling solar installations. By itself, a greater availability of financing might not significantly affect solar technology commercialization. But Part II of NECPA also mandated a study, by the Secretary of Energy, of the economic and technical feasibility of apartment building solar energy systems [54]. If 
the Secretary reports that the study found apartment building solar energy systems cost competitive and practicable, the availability of loan insurance may lead to a greater volume of apartment building solar installations. However, the growth in demand is unlikely to be similar to that which can be expected for residential solar energy systems because nothing comparable to an RCS program will be directed at multi-dwelling building owners. Without the flood of consumer information that the RCS programs will provide, it may be that only a small portion of apartment building owners who might take advantage of NHA loan insurance will even hear about it. Also, without guarantees, warranties, and requirements like those of the RCS program, product and workmanship quality may not be as carefully controlled. Solar industries concerned with apartment building applications would suffer if unsatisfactory apartment installations were common.

Finally, Part 3 increases permissible NHA insurance and loan amounts by up to $20 \%$ if the increased value of a residence is due to the installation of a solar energy system [55]. This increase should assure that purchasers of domestic solar systems are not penalized for such purchases.

\subsection{SOLAR EQUIPMENT INSTALLATIONS IN PUBLIC HOUSING}

Part 4 authorizes the Secretary of HUD to expend up to $\$ 10$ million each year to purchase and install energy conserving improvements, including solar systems, in existing public housing. Only solar energy systems that meet standards which the Secretary has yet to prescribe will be installed [56].

The $\$ 10$ million a year authorization may not have much effect on solar technology, because it is likely that only a small portion will be spent on solar devices. In fact, the Office of Management and Budget refused HUD's request for supplemental funds for 1979 to cover the cost of the program [57]. Part 4 also declares that newly constructed housing either insured by the Federal Housing Administration or assisted by the Farmers Home Administration must be significantly more energy efficient than existing structures. The standards of the Energy Conservation Standards for New Buildings Act of 1976 [58] are to be applied [59]. The application of the energy conservation performance standards to new housing should benefit solar commercialization. New residences will probably reduce their energy consumption per floor space area considerably by incorporating passive solar design. Solar water heating and active space heating and cooling systems should also become more widely used in attempts to comply with the energy conservation performance standards.

\subsection{MANDATORY ENERGY EFFICIENCY STANDARDS}

Part 4 also mandates that the Secretary of HUD, in cooperation with Secretaries of Agriculture, Treasury, Veterans Affairs, and Energy, must determine whether there is a need for mandatory residential energy efficiency standards. The Secretaries must study the practicability and problems of imposing such standards for all residential units. The Secretary of HUD must then report his findings and recommendations to Congress within a year of the date of enactment of NECPA [60]. If legislation requiring that all residences be subject to energy efficiency standards is recommended, the effects on solar technology commercialization could be substantial. Most dwellings would be in compliance with the standards, af ter installation of conservation measures such as additional insulation or weather stripping. A significant number of homeowners would probably 
choose to install solar energy systems so that they might consume more energy while complying with the standards. Mandatory energy efficiency standards would certainly stimulate the solar energy market.

\subsection{CONSERVATION PROGRAMS FOR SCHOOLS, HOSPITALS, AND LOCAL GOVERNMENT AND PUBLIC CARE BUILDINGS}

Title III of NECPA establishes grant programs for energy conservation in public or nonprofit schools, hospitals, local government buildings, and public care institutions. In order to receive grants, the governor of each state must apply to the Secretary of Energy. States are eligible for funds to cover up to $50 \%$ of the cost of preliminary energy audits and energy audits for nonprofit schools and hospitals, and local government and public care institution buildings. A preliminary energy audit is an inspection of the major energy using system of a building and a determination of the type and amount of energy consumed in that building. Energy audits are inspections that determine a building's energy consumption characteristics. They also determine appropriate energy conservation maintenance and operating procedures and indicate any recommended energy conservation measures [61]. Wheñ. a state has a good approximation of the energy conservation programs that are needed and has determined proper federal fund allocation among eligible institutions, it must promulgate a plan to implement the grant programs [62]. State plans must be submitted to DOE for approval. After plan approval, a state energy agency will solicit, evaluate, and rank applications for financial assistance from eligible schools, hospitals, units of local government and public care institutions. The state must recommend funding amounts (by building) for each applicant. The applications must then be sent to DOE, which will grant awards up to $50 \%$ of the cost of an energy conservation project if the state's recommendations are approved.

Schools and hospitals are eligible for funds to assist their installation of energy conservation measures, which will sometimes be solar energy systems. But, units of local government and public care institutions may only receive money for technical assistance programs. Technical assistance programs determine energy and cost savings likely to be realized as a result of modifying building maintenance and operating procedures. They also identify energy and cost savings likely to result from installing solar energy systems. They do not provide financial assistance for the purchase and installation of such systems [63].

The grant programs will result in some publicity for solar technologies. Many program participants will receive information about solar energy systems. However, according to Federal Energy Administration (FEA) experts who testified before the Senate Committee on Energy and Natural Resources, energy savings of 15-30\% could be realized by schools and hospitals through implementation of inexpensive conservation practices and measures. These experts said that an additional 15\% could be saved through more costly capital improvements [64]. Many building managers will probably select less expensive conservation practices and measures, rather than going to the considerable expense of installing a solar energy system. It is likely that much of the..available money will be allocated to less expensive, effective energy conservation practices and measures, and that few solar energy systems will be installed under the grant program. 


\subsubsection{School and Hospital Conservation Programs}

Part I of Title III of NECPA was designed to help schools and hospitals implement suitable energy conserving practices. It was also intended to aid them in determining appropriate energy conservation measures and installing such measures. Part 1 amends the Energy Policy and Conservation Act (EPCA) [65]. The amended EPCA provides that the governor of each state apply once each year to the Secretary of Energy for funds to cover up to $50 \%$ of the cost of preliminary energy audits and energy audits in the state's nonprofit and public schools and hospitals [66].

The state energy agency must then submit a plan to the Secretary of Energy. The plan must recommend energy projects for the state's schools and hospitals, and include estimated costs of such projects, along with a report on the results of the preliminary energy audits [67], an estimate of energy savings that will result from building maintenance and operating procedure modifications, and the installation of energy conservation measures in the schools and hospitals of the state. The state plan must include procedures to insure that funds will be allocated fairly among eligible energy conservation projects in the state, and to assure that all financial assistance received under the program will be expended in compliance with the state plan and NECPA requirements [68]. Most important for solar technology commercialization, the state plan must include a declaration of the extent of the state's commitment and the means by which the state will implement that commitment to encourage utilization of solar space heating, cooling, electric systems, and solar water heating systems [69]. While NECPA does not set a minimum acceptable commitment to promoting solar energy system installations, the Secretary does have the power to disapprove of any inadequate state plan [70]. A state that submits a plan giving little attention to the promotion of solar energy use could conceivably have to develop a more satisfactory plan. As a result, plan promulgators will devote some time to creating practicable and effective procedures to encourage school and hospital administrators to install solar energy systems where appropriate.

After a state has an approved plan, schools and hospitals may submit applications for program grants to the state energy of fice. The applications must include energy audit results of buildings for which funds are sought [71]. Applications must also include the applicant's name, certification of eligibility for federal assistance, a project budget, and an installation schedule for each proposed conservation measure [72]. In order to be eligible for solar energy system installation assistance, the building must have been evaluated in a technical assistance program that consists of studies specifying energy and related cost savings likely to be realized as a result of operation and maintenance procedure modifications or installation of energy conservation measures [73]. Technical assistance includes planning or administration of specific remodeling, renovation, repair, replacement, or insulation projects related to energy conservation in a building [74]. Funds are available under the program to assist states in paying for technical assistance programs [75]. Because technical assistance programs include evaluations of a building's solar conversion potential [76], the eligibility requirement that a technical assistance program be completed should help solar technology commercialization. It will assure that every school and hospital that receives funds under the program will have had a solar conversion potential assessment. Where such a conversion is practicable, the school or hospital will of ten receive federal assistance to install solar devices.

The expense of solar energy systems, as opposed to energy conservation measures such as thermostat adjustments and weatherstripping, will restrict acceleration in the rate of solar energy system installation that occurs as a result of these programs. The FEA expert who testified before the Senate Committee on Energy and Natural Resources estimated that between $15 \%$ and $30 \%$ of present energy costs could be saved through the use 
of relatively inexpensive energy conservation practices and measures. It is likely that a large portion of the available funds will be allocated to such projects. The remaining funds will be spent on all types of energy-conserving capital improvements. Solar systems may receive a very small share of the total appropriation. The authorized appropriations are $\$ 25$ million through FY79 for preliminary energy audits and energy audits; $\$ 180$ million for FY78; $\$ 295$ million for FY79; and $\$ 400$ million for FY80 for energy conservation project grants [77]. However, solar technology commercialization will benefit from the program in another way. The solar energy systems that are installed will of ten serve as demonstrations, introducing solar technology into communities that would otherwise be unfamiliar with it. Thus, school and hospital installations of solar energy systems may stimulate owners of other institutional buildings to install such devices.

The solar industry should benefit from the programs in another way. Institutions receiving federal funds under this program must report to the state after the completion of the assistance program or project on work done and problems encountered [78]. For the three years following completion of the program or project, assisted institutions must report annually on the actual energy consumption of assisted buildings [79]. The information contained in these reports should prove useful to the solar industry. The solar industry will be able to determine how well its products are performing, and will be able to modify those products that the data indicate are inadequate.

\subsubsection{Conservation Programs for Buildings Owned by Units of Local Government and Public Care Institutions}

Part 2 of Title II amends Title III of EPCA and deals with energy conservation programs for buildings owned and occupied by units of local government and public care institutions. It is designed to provide funding for energy audits and technical assistance programs. However, under this part of Title III, technical assistance programs consist of studies of the energy savings available from building maintenance and operation procedure modification or energy conservation measure installations. Unlike the school and hospital programs, planning and administration of construction work related to installation of conservation measures is not available as part of technical assistance programs [80]. The program does not provide financial assistance to units of local government or public care institutions for installation of energy conservation measures [81].

The Secretary of Energy must prescribe guidelines for the preliminary energy audits and state plans to implement the technical assistance programs [82]. After the Secretary has published the guidelines, the governors of the states may apply to the Secretary for grants to conduct preliminary energy audits and technical assistance programs. The Secretary may grant up to $50 \%$ of the cost of any project [83]. Solar technology commercialization should receive some benefit from this part of the program, because the technical assistance program must evaluate each inspected building's potential for conversion to solar energy systems [84. Thus, every building that participates in a technical assistance program will have an assessment of solar conversion possibilities. Some building operators may choose to have solar energy systems installed if the technical assistance report indicates it would result in significant energy cost savings. 


\subsection{PEDERAL PURCHASE AND DEMONSTRATION PROGRAMS}

Title $\mathrm{V}$ of NECPA proclaims federal solar heating and cooling demonstration projects, federal building solar energy system installations, and the Federal Photovoltaic Utilization Program.

\subsubsection{Federal Demonstration Program}

The demonstration program will aid solar technology commercialization by introducing such technology to communities that might otherwise be unfamiliar with it. Demonstration projects are to be located in areas in which a private sector market of solar energy equipment is likely to develop [85]. The likelihood that demonstration projects will result in private solar energy system installation around the project area is increased.

The program to install solar energy systems in federal buildings sets deadlines for federal building energy audits and retrofitting to minimize building life-cycle costs. Title $\mathrm{V}$ also mandates that new federal buildings and energy system designs no longer be selected for construction on the basis of their initial costs. Instead, both the initial cost and the costs of operation and maintenance over the building's useful life must be taken into account. Because the initial cost of solar energy systems is generally higher than that of conventional energy systems, but their operating costs are significantly lower, the use of lifecycle cost analyses will affect federal solar energy installations favorably. The mandate to retrofit federal buildings to minimize their life-cycle costs should result in solar energy equipment installations in some federal buildings. Part 3 of Title $\mathrm{V}$ will have its greatest effect on solar technology commercialization because of its mandate to use a life-cycle cost analysis when selecting new federal building projects [86].

F PUP was intended by Congress to result in low-cost production methods in the photovoltaic industry. If the program allows the implementation of such methods, the photovoltaic industry will have received a tremendous benefit. Photovoltaics will be reduced in price and will thereby become more competitive with conventional electricity sources. Increased competitiveness should bring increased demand, which should result in further economies of scale and lower product prices. FPUP could accelerate the development of economical photovoltairs significantly.

\subsubsection{Space Heating and Cooling Demonstration Project}

Part 2 of Title $\mathrm{V}$ sets up a program designed to demonstrate solar heating and cooling technology, through the installation of such technology in federal buildings. Buildings that will be eligible for the project are those that are owned or occupied by the United States or federal agency under a lease-acquisition plan [87]. The Secretary of Energy must first presoribe the procedure by which federal agencies are to submit proposals for dem onstration projects. He must also establish criteria to evaluate the various proposals [88]. Congress has declared that the criteria must promote the demonstration of as many types of solar systems as is feasible, and lead to the selection of projects at locations where a private sector market for solar systems is likely to develop [89]. Demonstrations of diverse solar technologies in areas where solar energy systems are appropriate should maximize the benefits of the demonstration projects to the solar industry. Congress has authorized appropriations of up to $\$ 100$ million through FY80 to carry out the demonstration program [90]. The projects will supply a valuable form of free advertising for the solar industry, in addition to creating a sizable market for solar products. 


\subsubsection{Solar Energy System Use in Federal Buildings}

Part 3 of Title V states a federal policy of promoting the use of solar energy systems in federal buildings [91]. Part 3 directs the Secretary to establish energy efficiency goals for federal buildings and to promote the attainment of such goals [92]. Part 3 also directs that future energy system cost evaluations consider the cost of a system over its useful life, rather than just its initial cost [93]. A life-cycle cost evaluation should benefit solar technologies because solar devices are relatively costly to install, but become competitive with conventional energy systems because of their relatively low operation costs. The Secretary must make information on the use of life-cycle cost methods available to the public [94]. If such information is widely used, it could have a significant beneficial effect on private sector purchases of solar technology.

\subsubsection{Energy Targets for Federal Buildings}

The Secretary must, after consulting with the Administrator of the General Services Administration, the Director of the National Bureau of Standards, and the Director of the Office of Management and Budget, prescribe energy performance targets for federal buildings. Energy performance targets should be the minimum building energy consumption that can reasonably be achieved [95]. The attainment of minimum practical energy consumption will probably entail the use of solar technology in some buildings. Large orders could greatly facilitate the commercialization of solar technology by supplying the financial support that some production processes may need in order to become economically feasible.

\subsubsection{Deadline for Energy-Saving Modifications of Existing Federal Buildings}

Part 3 mandates that all federal buildings with more than $1000 \mathrm{ft}^{2}$ of floor space must receive preliminary energy audits before 15 Aug. 80 . After the preliminary energy audits, every federal agency must select buildings that it controls for modifications to reduce those buildings' energy consumption. Modification of operating and maintenance procedures must be chosen over structural modifications or equipment installations when either would achieve energy conservation. At least $1 \%$ of the floor space that was preliminarily audited must be modified within a year of NECPA's enactment. By 1990, every federal building must be modified to minimize its life-cycle costs [96]. This time schedule should accelerate the installations of solar devices in federal buildings. However, because modifications of operating and maintenance procedures must be effected before equipment is installer, the number of solar deviccs in cxisting federal buildings should not greatly increase.

\subsubsection{The Federal Photovoltaic Utilization Program}

Part 4 sets out a program that is intended to expedite the purchase and installation of photovoltaic systems in buildings, structures, fixtures, or parts of these, that are owned or held under a lease-acquisition agreement by the United States or any federal agency [97]. The program should produce data on the performance of photovoltaic (PV) systems and stimulate the growth of a PV industry [98]. In fact, Congress has declared that the acquisition rate be sufficient to allow the industry to use low-cost production methods [99]. If Congress' goal is met, the PV industry will have received an important boost. If large government orders result in competitive PV prices, the nation will have gained 
substantially because a new cost-competitive source of electricity will become available. Photovoltaic electricity could provide a secure, reliable, and environmentally sound source of power for the nation.

\subsubsection{The Seeretary of Energy's Duties}

The Secretary of Energy must prescribe a program to evaluate various PV systems and purchase the most advanced and reliable systems that are available to meet FPUP requirements [100]. Up to $30 \mathrm{MW}$ of PV power capacity may be purchased by the Federal Government in each of the years 1979, 1980, and 1981. Ninety-eight million dollars are authorized to carry out the purchases mandated by this program [101], and should make it possible to bring PV costs down to a competitive level for many uses. DOE plans to implement the program in two stages. First, projects will be selected from among those proposed by federal agencies. The NECPA Joint Explanatory Statement declares that Congress intended that the program help small businesses and promote competition [102]. Once the selected projects have been installed, they will be evaluated by DOE. The latter stage should last for 3 years. Agencies that receive PV systems through FPUP must report to DOE within 60 days of completion of PV installation, noting the names of the manufacturers and installers of the PV systems, any problems encountered, and agency comments and recommendations. These reports will provide information on PV systems that should prove very useful to system manufacturers and installers. Even more useful will be the final reports that agencies must submit 3 years from the date of commencement of normal PV system operations [103]. Copies of the final reports must be sent to the manufacturers and installers of the systems [104]. On the basis of the information contained in the reports, manufacturers and installers can determine the modifications that would improve their product or service.

DOE must report annually to Congress regarding PV system designs that are believed to be most cost effective and perform most satisfactorily. Photovoltaic system life-cycle cost data must also be reported [105]. DOE is authorized to require that projects install instrumentation for collection of additional data on PV system operation, which should maximize the data value and lead to more informative annual DOE reports to Congress. The reports on optimal designs should prove extremely valuable to PV industries and small companies that cannot afford research programs, because the reports will contain information that will lead to better system designs. If small PV companies have access to such information, they may be able to make their products competitive with the products of companies with substantial research facilities.

\subsection{CONCLUSION}

NECPA should have a greater impact on the commercialization of solar technologies for buildings applications than any of the other statutes that comprise the NEA. The RCS program should stimulate a market for domestic solar equipment. The schools, hospitals, public care institutions, and units of local government programs, along with the federal demonstration and purchase programs, will create a federal market for larger solar energy systems and should result in private sector purchases of larger systems. 


\section{SEPI}




\title{
SECTION 3.0
}

\author{
THE ENERGY TAX ACT*
}

\subsection{INTRODUCTION}

The ETA represents the only comprehensive solar tax package that Congress has passed to date. The ETA provides for both a residential energy tax credit to homeowners [106] and an energy investment tax credit to businesses [107]. The residential energy credit is composed of two distinct energy credits: one for home conservation expenditures [108], and the other for renewable energy source property expenditures [109]. Although some aspects of passive solar systems may be eligible for the energy conservation credit, this section primarily addresses systems eligible for the renewable energy tax credit and the energy investment tax credit.

Homeowners may take an income tax credit of $30 \%$ of the first $\$ 2,000$ they spend for solar energy source property related to their principal residence. They may take $20 \%$ of the next $\$ 8,000$ they spend for such property, for a maximum credit of $\$ 2,200$. However, because the credit is not refundable, unless the homeowner's tax liability is equal to or exceeds the credit he is entitled to, he will have to take part of this credit in the next tax year. Nonetheless, the income tax credit will reduce both the initial and the total costs of solar energy systems for homeowners. Lower costs should lead to installations where solar equipment is cost-competitive with the conventional energy source used by the particular homeowner.

One of the biggest problems with the credit is that it is not available for passive solar components that are structural features of the dwelling. Passive systems are cost effective because they serve both energy saving and structural functions. While they cost more than conventional structures, they are designed to reduce the dwelling's energy consumption rate enough to compensate for higher cost with lower utility or home heating bills. Because passive solar components are not eligible for the residential income tax credit, fewer solar energy system applications will be cost competitive with conventional heating and cooling systems. Fewer passive homes will be built and passive commcrcialization will be slow. Passive snlar homes offer significant savings of nonrenewable energy and should be eligible for the credit so that NEA goals can be achieved.

The business investment tax credit is equal to $10 \%$ of the cost of qualifying energy property. That $10 \%$ may be subtracted from a company's income tax liability and added to the regular $10 \%$ investment credit for qualifying capital equipment. Thus, some industrial solar energy property purchasers may take a $20 \%$ investment tax credit. Even though the business investment credit will encourage industrial installations of solar energy systems, many believe that a $10 \%$ credit is not large enough to significantly affect such installations. The potential effect of the credit is also limited by the fact that it is available only through 1982. Many businesses may be unwilling or unable to take advantage of the credit unless Congress extends its lifetime. Only active solar energy equipment is eligible for the business investment credit. This exclusion of passive designs probably means that fewer businesses will construct passive solar buildings. Given the energy demand

*This section is the work of Steven Cohen, Boston University School of Law, as edited by Judy Howard. 
per square footage reductions available through passive designs, and Congress' declaration of a goal of restraining future nonrenewable energy source demand, the ineligibility of passive solar components for energy investment credits is foolish.

\subsection{THE RESIDENTIAL TAX CREDIT}

Approximately $22 \%$ of U.S. energy consumption is in homes, with nearly three quarters of that being used for heating, cooling, and ventilation [110]. Heating and cooling homes and buildings and supplying them with hot water uses about $25 \%$ of the energy consumed in the United States [111]. Since over 20\% of all natural gas and over 10\% of all petroleum is consumed in heating and cooling, the potential for savings through solar devices is tremendous [112].

On a life-cycle basis, solar water heating is usually less expensive than water heating using conventional fuels [113]. With the residential tax credit as an incentive, solar applications for domestic hot water are economically feasible for a number of states when contrasted against natural gas, heating oil, or electricity [114]. The residential credit incentive structure lowers the cost of solar hot water systems sufficiently to achieve economic feasibility. On the other hand, solar space heating costs between $\$ 10,000$ and $\$ 15,000$ for the average home, which is nearly twice as costly as conventional home heating [115]. As of 1977, the costs of a solar residential space heating syste $m$ with an incentive structure similar to the residential tax credit would not have been economically feasible compared with either natural gas or home heating oil prices [116]. However, when compared to an electric resistance space heating system, solar residential space heating (even without tax incentives) will become economically feasible in many states by 1985 [117]. Furthermore, the feasibility of solar space heating may change dramatically with escalating fossil fuel prices.

Congress enacted the ETA to reduce U.S. energy dependence upon imported petroleum. Congress hoped to achieve this objective by providing tax incentives for the production and conservation of energy within both the private and industrial sectors. Assuming adequate communication to the public of the availability of the tax incentives and market penetration of solar energy products, the demand for residential SHAC systems will be felt by solar manufacturers, retailers, and distributors.

One study that considered the impact of tax incentives similar to the residential tax credit concluded that the potential use of solar technologies in both domestic hot water applications and residential space heating would be measurably enhanced by such incentives [118]. It further concluded that the application of solar energy for residential space heating was currently competitive with electrical resistanoe alternativcs [119]. Ilowever, solar applications for domestic hot water heating still appear more promising than for residential space heating [120].

Currently, the direct effects of the residential tax credit on the homeowner are: a reduction in the total cost of a solar system by the amount of the tax incentive, and a reduction of the high initial costs of the solar system by the amount of the tax incentive realized [121]. The residential tax credit improves the relative attractiveness of SHAC systems vis-a-vis conventional energy sources, and the availability of the credit should stimulate some taxpayers to investigate the solar market. With the ETA, the homeowner who decides to become an energy producer receives a reward in the form of an income tax credit. The federal tax system no longer discriminates against the homeowner who elects to produce solar energy for his own use. 
Title I (Section 101) of the ETA provides a residential energy credit against personal income taxes for renewable energy source expenditures. The expenditures must be related to the taxpayer's principal residence, and the residence must be located within the United States [122]. To be eligible for the full residential energy credit, at least $80 \%$ of the use of the residence must be for personal residential purposes [123]. If more than $20 \%$ of the energy property is used for business purposes, the taxpayer must allocate his solar expenditure between business and residential use [124]. If the taxpayer originally added the cost of the energy property to the base value of his residence, he must reduce that value by the amount of the credit [125]. Members of condominiums are allowed to deduct a pro rata share of solar expenditures made for the benefit of the entire complex [126].

The incentive structure allows for a $30 \%$ income tax credit for the first $\$ 2,000$ spent for qualifying solar equipment and a $20 \%$ credit for the next $\$ 8,000$ spent, for a maximum credit of $\$ 2,200$ towards systems that cost $\$ 10,000$ or more [127]. These expenditures include material and labor costs properly allocable to on-site preparation, assembly, or installation of solar energy equipment [128].

Renewable energy source property qualifying for the residential tax credit, when installed in connection with a dwelling, is defined as property that transmits or uses: solar energy or any other form of renewable energy that the Secretary of the Treasury [129] specifies by regulations, for the purpose of heating or cooling or providing hot water for use within such dwelling, or wind energy for nonbusiness residential purposes [130]. However, conventional backup systems that supplement the renewable energy source equipment in heating or cooling the residence do not qualify for the credit. Renewable energy source property also includes additional devices (not yet specified by the Secretary) that rely up on renewable energy sources for heating or cooling or providing hot water for use within a dwelling [131]. To qualify, property must be new, expected to remain in operation for at least 5 years [132], and must meet performance and quality standards (not yet issued) specified by the Secretary [133]

The Treasury Department has proposed rules that further define solar and wind energy equipment [134]. Examples of solar energy equipment include collectors (designed to absorb sunlight and create hot liquids or air), storage tanks (to store hot liquids), rockbeds (to store hot air), thermostats (to activate pumps or fans that circulate hot liquids or air), and heat exchangers (to utilize hot liquids or air to create hot air or water) [135]. The proposed rules define wind energy property as equipment that transmits or uses wind energy in any form for personal residential purposes, when installed in connection with a dwelling [136]. Examples of wind energy equipment include windmills, wind-driven generators, and power conditioning and storage devices that use wind to generate electricity or mechanical forms of energy [137]. The proposed rules for the residential tax credit specifically state that solar energy property includes passive and active solar systems, or a combination of both [138].

A significant limitation on the residential tax credit's effectiveness is that it does not provide relief to taxpayers whose credits exceed their income tax liability. In short, the residential tax credit is not refundable [139]. The tax bracket status of lower income groups prevents them from realizing the residential tax credit. If they are fortunate enough to have a small federal tax liability, the full effect of the credit cannot be realized in that year. Only middle and upper income taxpayers have a high enough current tax liability to take advantage of the residential credit. 
Instead of being refundable, the residential tax credit can be carried forward through 1987. Tax incentives with carry-back and carry-forward provisions are of ten difficult for the average taxpayer to understand. The carry-forward feature of the residential tax credit complicates the homeowner's tax return procedures. Taxpayers that are unfamiliar with filing tax returns or unable to obtain professional assistance might be deterred from installing solar equipment and claiming the tax credit [140]. The effectiveness of the residential credit is limited because its nonrefundability runs contrary to Congressional objectives. Furthermore, such provisions tend to cause administrative problems for the Internal Revenue Service (IRS) when taxpayers misconstrue them and file erroneous tax returns.

If the ETA was amended to make the residential credit refundable, individuals who are not required to file returns might be eligible for a refund. Thero would be some prublem locating those eligible nontaxpayers. However, this is not a serious problem. Information concerning procedures for claiming a refund could be disseminated through existing solar information channels; e.g., with consumer protection literature. Also, our system of taxation is not predicated on the notion that the IRS locate taxpayers eligible for tax refunds. Although some eligible nontaxpayers might not be aware of the existence of a refund, a refundable credit is superior to a tax credit that can only be taken when one's tax liability is sufficiently large.

The proposed rules also restrict the residential credit's effectiveness by limiting its applicability to those portions of the solar system whose primary purpose is to transmit or use solar radiation. Solar energy system materials and components that have a significant structural function are not included within the term "solar energy property" and do not qualify for the credit; e.g., costs of roofs, windows, skylights, walls, and greenhouses [141]. Renewable energy source property does not include any energy source medium that has a primary function other than storage; e.g., a swimming pool.

Furthermore, active and passive solar systeme are not well-deflned in the proposed rules for the residential tax credit [142]. The IRS definition of a passive system based on the use of conductive, convective, or radiant energy transfer is poorly drafted and illusory. Well-designed tax legislation should define solar energy terms such as active, passive, and renewable energy source, in order to minimize interpretive difficulties that may result. In the meantime, detailed guidelines and criteria should be published to enlighten the taxpayer as to exact qualifications.

Determining the passive solar systems that qualify for the residential tax credit is mainly a problem of interpreting Congressional intent. There is no clear, unambiguous indication of Congressional intent as to which passive systems qualify for the residential tax credit. Nelther the House bill, Senate amendment, nor conferencc agreement inukes it clear which passive systems are eligible for the credit. However, legislative history strongly suggests that Congress' intentions were to include all passive systems within the tax credit legislation. During Congressional debate on the Senate amendment to the House bill, Senator Percy noted that the amendment left the definition of qualifying passive solar equipment unsettled [143]. The Senator assumed that the IRS, in conjunction with DOE, would define passive solar equipment in such a way that all known passive techniques would be given a fair credit [144]. In the Senate Finance Committee, the or iginal residential credit was proposed to include only active solar systems [145]. However, at Senator Haskell's request, the definition of solar energy property was expanded to specifically include passive as well as active systems [146]. There is no legislative history to suggest that it was Congress' intent to exclude passive solar systems that serve dual functions; i.e., structural as well as energy producing or conserving. 
Solar water heaters have been sold by the hundreds of thousands, and solar swimming pool heaters are becoming increasingly popular. [147]. It can safely be assumed that Congress intended to exclude luxurious decorative storage facilities such as jacuzzis and swimming pools. Although allowing tax credits for solar swimming pool heaters would have a positive effect upon the commercialization of that product, Congress explicitly excluded swimming pools from the credit by allowing only those items with a primary function related to the collection, storage, distribution, or control of solar energy [148]

The IRS may favor a limited application of the residential credit to passive systems because of the problems in distinguishing between structural and purely energy conserving elements [149]. The Administration's Domestic Policy Review (DPR) reasons that the policy of limited application is due to the difficulty of distinguishing between solar system costs and the costs of the house itself [150]. DOE has proposed setting guidelines that would allow the tax credit only for those components of the structure that are clearly elements of a comprehensive passive system [151]. However, such guidelines would not help settle the controversy as to which passive system elements should qualify for the credit. The failure to include structural components of passive solar systems that not only conserve energy but also serve a structural function, will result in far less than the maximum possible rate of passive commercialization.

The government's inability to adequately clarify and define those elements of passive systems that qualify for the residential credit may have disastrous effects upon solar comm ercialization. Eligibility criteria should be designed to achieve maximum savings per dollar spent. Other than the the proposed rules, Federal tax form 5695 (which is used to apply for the residential credit) is presently the only guideline available to determine which solar devices qualify for the credit [152]. The problem for the solar manufacturer is that he cannot get a prompt advance ruling on whether his product will qualify for the tax credit. This indecisiveness plays havoc in the marketplace, especially with marketing strategy. Furthermore, no assurance can be given to consumers that a new solar product will qualify for the tax credit [153].

A solar manufacturer may seek certification from the Treasury Department that his product meets the definition of renewable energy source property. The Assistant Technical Commissioner will certify the product or notify the manufacturer that his request was denied [154]. A solar manufacturer may also seek approval for the addition of his product to the Treasury's list of renewable energy sources [155]. The Secretary will perform all certifications; however, such certification does not insure that the product satisfies any applicable performance and quality standards [156]. Only energy sources available in exhaustible amounts will be considered for addition to the approved renewable energy source list [157].

The IRS has interpreted Congressional intent very narrowly to exclude passive systems that serve both energy saving and structural functions. This interpretation ignores the underlying objectives of the act itself [158]. Passive systems become cost effective precisely because they serve a dual purpose. A homeowner does not have to spend double for both structural and energy saving additions to his residence. Rather, he need only pay slightly more than purely structural costs to obtain a passive energy saving system. The application of passive design principles that take energy efficiency into account and make maximum use of direct sun power in the design of the structure is good economics. It is the role of both Congress and the IRS to make those economics more feasible for the residential homeowner. 


\subsection{THE BUSINESS INVESTMENT CREDIT}

Title II, Section 301 of the ETA provides changes in the business investment credit to encourage consideration of, or conversion from conventional energy sources, and to encourage new solar energy technology [159].

Fuel-saving incentives, whether they be tax credit or government-backed loans, are needed to stimulate a mass industrial market for solar thermal systems in the near future [160]. Such a market depends upon the the introduction of new industrial applications for solar technologies. Current industrial applications for solar-generated heat include producing process steam, preheating combustion air and boiler feedwater, providing process hot water, and supplying hot air for dehydration. The potential for solar process heat in industry by the year 2000 is about $35 \%$ of the total use of process heat in that year [161]. The technical feasibility of solar process heating systems is not in doubt; it is only the current cost-efficiency that is uncertain.

There is real concern about the cost-effectiveness of solar process heating systems and whether industry will find it economically attractive to purchase, install, and operate those capital-intensive systems [162]. Any industrial investment will have to yield an af ter-tax rate of return at least equal to the company's capital cost. Therefore, a prerequisite for industrial users considering installation of alternative energy sources is the assurance of an investment return that is sufficiently attractive to compete for the capital required to finance the project.

An industrial user's investment decision is normally guided by the economics of a certain return on invested capital. However, fuel availability or regulatory restrictions could force an individual user to change to a solar technology at new or existing plants. This type of industrial investment ignores the conventional cost-effectiveness analysis. The business investment credit of the ETA would have no effect on accelerating solar commercialization in such an environment.

The investment tax credit is an amount subtracted from a company's income tax liability that is equal to a percentage of the cost of qualifying capital expenditures. The energy percentage is equal to $10 \%$ of the cost of qualifying energy property, and is in addition to the regular $10 \%$ investment credit available for qualifying capital expenditures [163]. Therefore, energy property may qualify for both the business energy credit and the regular investment credit [164]. Solar energy property qualifies for the business energy credit, but may not qualify for the regular investment credit if the property is a structural component of a building. The energy credit will be available for property placed into service before 1 Jan. 83 .

Qualifying energy property is defined to include alternative energy property, solar or wind energy property, specially defined energy property, and recycling equipment [165]. All energy property must be new depreciable property with a useful life of 3 years or more [166], whose original use commences with the taxpayer. Also, public-utility-owned property is specifically excluded from eligibility for the energy credit [167].

Alternative energy property includes specific types of equipment that use an alternative substance as a primary fuel [168]. An alternative substance is an energy producing substance other than oil, natural gas, or a by-product of oil and natural gas [169]. Alternative energy property that qualifies for the business credit includes boilers (the primary fuel for which is an alternative substance); burners for a combustor (if the primary fuel is an alternative substance); equipment for converting alternative substances into synthetic 
liquid, gas, or solid fuel; and equipment designed to modify equipment that uses oil or natural gas as a fuel or feedstock, where an alternative substance provides at least $25 \%$ of that fuel or feedstock [170]. Solar or wind energy property includes any equipment that uses solar or wind energy to generate electricity, heat, cool, or provide hot water for use in a structure [171]. Specially defined energy property includes recuperators, heat wheels, regenerators, heat exchangers, waste heat boilers, heat pipes, automatic control systems, turbulators, preheaters, combustible gas recovery systems, economizers, or any other property specified by the Secretary [172]. The principal purpose of this category is to reduce the amount of energy consumed in existing industrial or commercial processes. The Secretary is expected to consult with DOE and the Bureau of Standards before specifying additional eligible items. Recycling equipment means any equipment used exclusively to sort and prepare solid waste (including biomass) for recycling. It includes any equipment used to convert solid waste into a fuel or useful energy source such as steam, electricity, or hot water [173].

Currently, only active solar systems qualify for the energy investment credit. The definition of solar and wind energy equipment does not include passive solar systems. To date, the Treasury Secretary has not issued any performance or quality standards, regulations, or qualification guidelines. As a result, commercial and industrial sectors lack important information concerning the qualification of their solar investments for the investment credit.

Passive investments do not qualify for the investment credit. There was Congressional concern that special rules for passive systems (which may be lengthy and complex) would be needed to regulate eligibility for the credit. It was believed that there would be no credit control of passive designs such as ordinary windows, skylights, and greenhouses. These were some of the administrative problems encountered by California and New Mexico in deciding whether passive designs should be eligible for state income tax credits [174]. Also, some Congressmen believed that making passive designs eligible would considerably deplete the Treasury.

These arguments for restricting passive applications are rebuttable, and the need for special rules is grossly exaggerated. Any incentive program is likely to cause a significant Treasury depletion. Congress must determine its spending priorities regarding solar comm ercialization as a means of reducing U.S. energy consumption. There is no indication that the fiscal drain from passive eligibility would be unacceptably severe. As solar technologies develop and become more refined, it will become possible to define solar terms with greater certainty [175]. This is an administrative problem that can be solved by the IRS with technical assistance from DOE, and should not become an added barrier to the commercialization of passive designs.

To qualify for the investment credit, equipment must meet any performance and quality standards prescribed by the Secretary [176]. The recapture rules under the regular invest ment credit also apply to the energy credit. Any qualifying property that has been financed by tax-free industrial development bonds may take only a $5 \%$ credit rather than the full $10 \%$ credit [177].

Due to the lack of regulations, rules, or guidelines for investment credit eligibility, commercial and industrial concerns cannot make informed decisions about solar investments. There is also much confusion because of the definitional problems encountered with active and passive designs [178]. It may be necessary for businesses to consult corporate counsel or obtain legal advice regarding the eligibility of solar investments. This is counterproductive to the intent of Congress in passing the ETA. Smaller 
businesses may not be able to afford legal advice regarding eligibility and may be unwilling to invest in solar facilities because of the risk involved. A tax incentive is of little value if it creates apprehensions that cause businesses to avoid it.

The IRS has delineated certain property that does not qualify for the energy credit [179]. For example, hotel or motel property that primarily serves transient guests, property owned or leased to a government unit, or property for which special 60-month amortization is taken does not qualify for the energy credit [180].

Unlike the residential energy credit, the investment credit for solar or wind energy property is refundable [181]. However, the allowable investment credit for alternative energy property, specially defined energy property, and recycling equipment is not refundable and may not exceed the company's current tax liability [182].

The $10 \%$ ETA investment credit will have a positive effect on solar commercialization that cannot accurately be measured. There is a great amount of pessimism concerning the effectiveness of the credit. Many believe that the $10 \%$ credit is too small to have a measurable effect upon industrial process users. Recently, the Solar Energy Industries Association (SEIA) proposed commercial tax credits ranging from $20-45 \%$ of the solar investment, depending upon the amount of the expenditure and the year in which it was taken [183]. The Administration's DPR recognized that the investment credit's size would lessen its impact on the industrial process heat market [184]. It is apparent that there is widespread concern regarding the low percentage of the credit and the amount of tax savings that will be realized.

Users may be unable to commit funds for solar conversion or expansion in order to take advantage of the credit before it expires (31 Dec. 82). Innovative industrial users may take advantage of the credit, but conservative firms may adopt a wait-and-see attitude concerning the economic feasibility of solar applications. Furthermore, the planning effort required for plant expansion or retrofitting may take several months or years, and the credit may have lapsed before solar equipment purchase or installation. Congress might extend the life of the investment credit; however, few companies may be willing to commit themselves on the basis of that possibility.

Industrial acceptance of solar technologies requires financial incentives to lower the initial system costs. Without these incentives, industrial investment in solar technologies will not be significant and the rate of solar commercialization will not be optimal. If solar process heating is to contribute meaningfully to future U.S. energy needs, it must be subsidized by financial incentives until it becomes cost effective. The failure to extend the investment tax credit past 1982 into the late 1980 s could have dramatic negative eff ects upon solar commercialization.

Should the initial costs of solar facilities decrease sufficiently to become cost effective without tax incentives, the failure to extend the investment credit could be justified. However, even the most optimistic forecasts do not predict cost-effectiveness by 1982 . Furthermore, the regular investment tax credit (for which solar systems may also qualify) is scheduled to decrease from $10 \%$ to $7 \%$ on 1 Jan. 81 [185]. This will further increase the high initial costs of solar systems.

Industrial acceptance of solar systems will depend upon three factors: (1) a substantial reduction in the initial solar system cost, (2) continued shortages and price escalations of fossil fuels, and (3) the rapid advancement of government-sponsored financial incentives [186]. The energy investment credit will yield immediate tax savings for investments in 
solar or wind energy property. The credit will be realized for alternative energy property, specially defined energy property, and recycling equipment if the company's current tax liability exceeds the amount of the credit.

Presently, most of the companies in the solar heating and cooling industry are in the small business category [187]. The small business' tax liability size of ten limits the use of nonrefundable credits. With this in mind, Congress included (in Section 301 of the ETA) a refundability provision for solar and wind property. This allows companies with small tax liabilities to take advantage of the investment credit. The refundability provision serves a dual function. First, it provides immediate cost reductions to small companies that purchase and install solar systems. This reduces the high initial cost barrier to solar acquisitions. Second, it increases solar and wind product demand within the marketplace. Small solar manufacturers will benefit from a subsidized, growing solar market, and may expand their facilities to meet increased product demand.

Many Congressmen (especially those in the Congressional Solar Lobby) fought for refundable investment credits for all qualifying property. They attempted to establish refundable credits as a precedent for future solar tax incentives. Other factions were opposed to refundability provisions because of the resultant financial burden placed on the Treasury. Consequently, only solar and wind energy property are eligible for a refund. This makes little practical sense. Refundability provisions for qualifying property should not be compromised arbitrarily. In the interests of accelerating solar commercialization, all qualifying investment credit property should be refundable.

\subsection{CONCLUSION}

The ETA will encourage homeowner and business installation of solar energy equipment. The residential tax credit will not maximize residential solar technology commercialization because it is not refundable. It will not acheive a high level of nonrenewable energy source conservation because many passive solar system components are not eligible for the credit. Nonetheless, the residential tax credit should result in a substantial number of residential solar energy system installations. The energy investment credit appears to have some deficiencies: it is due to expire too soon, passive systems are not eligible, and the credit amount is not large enough to have significant impact. Further solar incentive legislation should remedy some of ETA's deficiencies. 


\section{SEPI数}


SECTION 4.0

\section{THE PUBLC UTIITY REGULATORY POLCIES ACT}

PURPA was designed to accomplish three goals [188]: (1) to promote additional conservation of electric and gas energy, (2) to promote more efficient use of power utilities' capital equipment, and (3) to provide more equitable rates for energy consumers [189]. These goals are advanced by setting forth rate prototypes that must be considered for adoption by authorized state utility regulatory agencies [190]. The prototypes reflect the true cost of serving various classes of consumers and should result in some conservation. PURPA also requires that electric utilities exchange (buy and sell) power with qualified cogenerators and interconnect with other utilities in order to pool their powerproducing capacities [191]. This requirement should result in more efficient use of capital equipment. Finally, the act authorizes funds for loans to facilitate new small hydroelectric projects [192] and studies of possible hydroelectric installations.

Titles I and III address standards for utilities that sell electricity and natural gas at the retail level. They provide that persons [193] selling electricity or natural gas for consumption (rather than resale) must consider the adoption of certain rate-making standards. The standards are meant to promote electrical energy conservation, efficient use of utility resources, and equitable rates for all utility customers [194].

The effect of Titles I and III on solar energy is indirect. Certain standards that are established, such as time-of-day rates [195], seasonal rates, [196] interruptible rates [197], and load management techniques [198] may enhance the attractiveness of solar energy systems to certain users. They would do so by reducing the utilities' costs of supplying supplemental energy to solar energy users. Some utilities have objected to charging solar energy system users the same rates as residential customers. The utilities claim that solar energy users would not be paying for their share of the capital investments [199]. PURPA standards designate techniques by which utilitities can reduce power demand. The need for further capital investments can thus be minimized and utilities can charge attractive rates to solar energy system users. Utilities are not required to adopt any of the standards, but it is in their economic interest to employ standards that would result in lower capital costs.

Title II encourages decentralized energy production by mandating that certain small energy producers, such as cogenerators and WECS, be allowed to exchange energy with utilities. It provides that the Federal Energy Regulatory Commission (FERC) promulgate criteria by which to select small producers who may participate in such energy exchanges [200]. Title II also provides for a FERC study on the possible advantages of "pooling," in which utilities share their energy. The study is to assess the potential for energy savings, efficient capital utilization, and increased reliability that might be realized by pooling [201]. The resul ts of this study, which should be reported to Congress by mid-1980 [202], will provide information on the potential for reducing the need for capital investments through sharing energy production capacities. If a significant reduction can be achieved by such cost-effective methods, some utilities will begin to pool. Their rates should then be reduced and solar energy systems will become more cost effective.

Title IV covers the establishment of a low-head hydroelectric power program. It provides funds and other incentives for the installation of generators with up to $15,000 \mathrm{~kW}$ capacity at existing dam sites. This title will obviously benefit the development of hydroelectric facilities. Other solar technologies may benefit indirectly from the program. 
When solar energy systems produce more energy than can be immediately consumed, the excess may be used to pump water into an impoundment. Hydroelectric generators can convert that stored water into electricity when needed. This program, by promoting the installation of hydroelectric generators at additional sites, increases the likelihood that hydro storage will be available to users of solar devices.

Title V deals with crude oil transportation systems, and does not influence solar energy.

Title VI contains three sections that may affect solar energy. One section provides for a study by the Secretary of Energy of PURPA's effect on state utility agency rate. setting. The results of the study must be reported to Congress by the end of 1979, and will provide information on whether PURPA has resulted in the attainment of Congress' goals. Congress may then alter any provisions that are not effective. Title VI also provides that the Secretary of Energy may cooperate with the Canadian Government in constructing transmission lines to carry electrical power from areas of low demand to areas of high demand, if such lines would result in energy conservation and maximize the efficient use of utility resources. This provision could help solar energy users by minimizing utility capital costs and thereby reducing the rates that solar-energy-using utility customers are charged.

Finally, Title VI provides for funds to aid the National Association of Regulatory Utility Commissioners in creating an institute that will research, collect, and disseminate information on utility regulatory issues, utility rate making, and other topics useful to state regulatory authorities. The information will be available to the public. Convenient access to such information may help solar energy proponents argue for utility rates that will treat solar energy system users fairly. Each title of PURPA is discussed in the following paragraphs, with emphasis on provisions that may directly influence solar energy system users or manufacturers.

\section{I ELECTRIC UTIITYY RETAIL POLICIES}

Title I sets forth policies for the regulation of electric utility retailing. Congress declared three goals to be reached by implementation of this title: (1) the conservation of utility-supplied energy, (2) promotion of the most efficient use of utility capital and resources, and (3) rate structures that would treat every class of electric consumers fairly [203]. All three of these purposes affect solar technologies. If the rate of increase of the energy demand placed upon electric utilities is decelerated through conservation techniques, the utilities will not need to invest as much in new power producing and transmitting facilities. Consequently, utility rates will not increase as sharply. Solar system manufacturers will have lower operating costs and may reduce the price of their product accordingly. However, if electricity rates do not increase substantially, fewer potential solar system users may decide to install such systems. Optimal efficiency in the use of electric utility resources should also lessen the need for new electricity producing and transmitting equipment. Greater efficiency will beneficially affect solar system users and the solar industries. The third purpose (equitable rate structures) should have a favorable effect on solar technologies if the first two purposes are achieved. If utility capital costs are reduced through conservation and efficiency, each customer's share of the capital costs should be insignificant. His bill will reflect the cost of energy he has consumed less the capital costs and should be considerably lower than those of conventional energy consumers. More utility consumers should install solar systems as energy cost savings improve. 


\subsubsection{Federal Standards}

PURPA \$111 sets out voluntary rate standards that all state electric utility regulatory agencies must either adopt or reject. They must hold public hearings before reaching a decision on the standards. Electric utilities that are not controlled by a state regulatory agency must also consider these standards:

- cost of service: rates reflecting the cost of providing electric service to a groups of consumers with similar electricity use patterns;

- declining block rates: a prohibition of cheaper rates for large volume consumers except where the cost of the energy actually decreases as consumption increases;

- time-of-day rates: rates that reflect the cost of providing electricity at various times of the day;

- seasonal rates: rates that reflect the cost of providing electric service at various times of the year;

- interruptible rates: rates that reflect the cost of providing electric service to commercial and industrial utility customers that agree to permit the utility to cut off service for short periods if the system power demand strains the utility's capacity; and

- load management techniques: techniques that a regulatory agency or a nonregulated utility determine are cost-effective ways of providing reliable service and managing a utility's energy or capacity demands.

Although regulatory agencies and nonregulated utilities must make written statements explaining their rejection of any standard available to the public, they do not have to adopt any of the standards [204].

The standards are designed to equitably allocate electricity costs. They should reduce peak demand by reflecting the cost of supplying electricity when demand is very high in the rates charged for that electricity or by encouraging utilities to find ways to lessen peak demand. A reduction in peak demand would reduce utility capital costs. With a larger proportion of energy to capital costs in utility bills, solar energy utility customers would have a greater advantage over conventional energy users; their bills would be significantly smaller because they use considerably less utility energy.

State authorities and nonregulated utilities must report annually to the Secretary of Energy regarding individual activity on each standard. The Secretary, in turn, must report that information and recommendations for legislation or other federal action needed to fulfill the purposes of Title I to Congress [205]. This requirement will provide Congress with information on the statute's adequacy in its purpose and will probably lead to future modifications of statute provisions.

The Secretary of Energy, any affected electric utility, or its customers may intervene in rate-making proceedings in order to introduce or participate in the consideration of any standard or other measure likely to result in achievement of the title's purposes [206]. Such an intervenor is entitled to all the parties' relevant information. If the intervenor is a consumer and his participation is necessary to the representation and approval of his position, he is entitled to compensation for reasonable costs incurred by his participation. He may have to establish that the denial of such compensation would result in 
personal hardship and that all persons with similar interests in the proceeding shared their legal representation. The right to intervention and compensation should benefit some solar energy system users by giving them consideration in the rate-making process. With such an opportunity, solar users may be able to obtain utility rates that will reflect the reduced amount of utility power that they consume.

\subsubsection{Electric Utility Information Requirements}

Every electric utility must gather information that will allow FERC to determine the costs of providing electrical service [207]. FERC must prescribe rules that will result in data collection on the cost of service to each class of electric consumer and the daily demand curves for each class [208]. This information must be made available to the public by each electric utility. 'I'he gathering and presentation of such information may help solar energy customers decide whether to intervene in an attempt to obtain more equitable rates.

\subsection{INTERCONNECTION, POOLING, COGENERATION, AND SMALL POWER PRODUCTION}

Title II amends various parts of the Federal Power Act (FPA) [209] in ways that will affect solar technologies. It also provides for a study of the potential energy and capital utilization efficiency of pooling. If utilities choose to take advantage of efficiencies available through pooling and reduce their need for capital improvements, solar system producers and solar users' rates will be reduced accordingly. This title also prescribes rules that will encourage cogeneration and small power production [210].

\subsubsection{Interconnection}

PURPA \$202 amends Part II of FPA by giving FERC the authority to order the connection of any cogeneration facility or small power production facility to the transmission lines of any electric utility, any federal agency that sells electricity, or any qualified cogenerator or small power producer. A cogeneration facility produces both electricity and some other useful form of energy, and a small power production facility uses biomass, water, or a renewable energy source that produces up to $80 \mathrm{MW}$ of electricity. Qualified cogenerators and small power producers are those that satisfy commission-prescribed standards [211] and are owned by persons whose business is not the generation or sale of electricity (except electricity generated from cogenerators or small power producers) [212]. FERC may also direct that necessary measures (e.g., enlargement of facilities or improved maintenance) be taken in order to effect such a connection. Of course, the entities that benefit from such directives must pay for the reasonable cost of work done in accordance with them [213]. FERC mandates must promote conservation of capital or energy, maximize the efficient use of resources, or improve the reliability of the affected electric utility system or federal power marketing agency [214]. If FERC finds that the directive will result in energy or capital conservation, or optimal efficiency in the use of resources, the rates should be lower than normal. Lower rates and capital cost components will result in reduced rates for solar energy system users and solar device manufacturers. 


\subsubsection{Wheeling}

PURPA \$203 amends Part II of the FPA and enables electric utilities and federal power marketing agencies to apply to FERC for an order requiring any electric utility to provide power transmission services to the applicant. Such power transmission services are known as wheeling. An order may be issued if (after a hearing at which affected parties present their arguments) FERC finds that such an order would result in significant energy conservation, substantially promote efficient use of electricity generating or transmitting facilities or utility resources, or improve the reliability of electric service.

FERC must determine whether an order requiring interconnection or wheeling would result in an uncompensated economic loss for the affected electric utility, qualifying cogenerator, or qualifying small power producer [215]. FERC must also ascertain whether such an order would unduly burden one or more of the previously listed entities, or significantly reduce the reliability of any electric utility subject to the order [216]. Finally, FERC must determine if electric utility customer service will remain adequate after the utility has complied with the order [217]. Even if FERC ascertains that unacceptable consequences will not follow the issuance of an order, none may be issued until the applicant has demonstrated its willingness and ability to compensate the affected party for the resultant costs of compliance. FERC must give reasons for its decision if it denies an application for an order [218].

Some of these FERC restrictions may completely negate the opportunities that were provided to cogenerators and small power producers. For instance, will any uncompensated economic loss justify the denial of an application for an order? How large a burden would be an undue burden, leading to the denial of an application? If either of these limitations is interpreted broadly, relatively few orders for interconnection or wheeling may be issued. Interconnection or wheeling could often make the difference between a successful cogenerator/small power producer and a failure. Their operators may need the security of utility backup service or the anticipated income from selling excess power. Such facilities may not be economically viable unless they can exchange power with utilities and transmit any unneeded power that they produce.

FERC is given the power to exempt any electric utility from state laws prohibiting pooling [219], if it finds that the pooling is designed to increase the efficient use of utility facilities and resources [220]. When pooling results in the need for less capital improvement, it will keep electric rates relatively low. Therefore, a provision that eliminates some of the barriers to pooling also benefits solar system producers and users by restraining the capital cost component of utility rates. Solar energy system users pay significantly less for their utility service than conventional energy users, resulting in more cost-effective solar energy systems.

\subsubsection{FERC Study of Pooling}

FERC must investigate the opportunities for energy conservation, efficient use of utility capital and resources, and increased utility service reliability that is available through pooling [221]. It may recommend that utilities enter into voluntary pooling arrangements because of the beneficial results. 


\subsubsection{Cogeneration and Small Power Production}

FERC must prescribe rules for electric utilities that it determines are necessary to "encourage cogeneration and small power production" [222]. The rules must require that electric utilities offer to exchange (buy and sell) electricity with qualifying cogenerators and small power producers. But, the rate at which a cogenerator or small power producer may sell electric power to a utility may not exceed the price such a utility would have paid for power from another source, or for producing that power itself [223]. This provision may not greatly "encourage" cogeneration and small power production. Utilities can probably produce energy at least as cheaply as most cogenerators and small power producers. The latter may not be able to realize much profit on their sales to utilities. However, they will have a market for the energy that they cannot use. Section 210 (c) provides that electric utilities must not discriminate against cogenerators or small power producers in setting their rates for electricity sales.

FERC must prescribe rules by which qualified cogenerators and small power producers may be exempted from certain federal and state laws and regulations [224], when such exemption is proven to be necessary in order to encourage their production [225]. Except for small power producers that rely on biomass as their primary energy source, only those that have less than a 30-MW production capacity may be exempted [226]. This immunity from certain laws and regulations was intended to encourage cogeneration and small power production; however, some type of government subsidy should be available until the cost of such energy production becomes comparable to the cost of utility energy production.

\subsubsection{Exemptions for Certain Hydroelectric Facilities}

Title II amends Part I of the FPA by adding that FERC may exempt hydroelectric facilities of 15-MW capacity or less from those requirements [227]. To be eligible, the facilities must not be on federal land and must use water from conduits that were designed primarily to distribute water, rather than to supply energy for hydroelectric generation. This provision, because it applies only to facilities using water from distribution conduits, may not have much impact on hydroelectric industries. However, it benefits certain lowhead hydroelectric producers by allowing them to avoid requirements that they would normally have to meet.

\subsection{NATURAL GAS UTHITY RETAIL POLICIES}

Title III covers retail policies for natural gas utilities. It is designed to promote the conservation of gas, the most efficient use of gas utility capital and resources, and equitable rates for gas utility customers [228]. If gas utility resources are used efficiently, utility capital costs will be reduced. If rates are then made equitable, the utility bills of solar energy system users should be appreciably lower than those of utility-supplied customers.

\subsubsection{Federal Standards}

This title requires that all state gas utility regulatory authorities and all nonregulated gas utilities conduct hearings on the adoption of federal standards set forth in the act [229]. 
The only standard that might have any effect on solar technology is one that covers gas utility advertising. Utility advertising designed to influence public opinion about legislative, administrative, or electoral matters, or to promote utility services or appliances, must generally be funded by shareholders or utility owners [230]. However, expenditures for advertising that is intended to promote the use of energy-efficient appliances or services may be recovered from other sources [23l]. This standard must be adopted if it is generally appropriate, fulfills the purposes of the title, and is consistent with applicable state law [232]. If a state regulatory authority or nonregulated utility chooses not to adopt either of the standards, it must make a written explanation of its decision available to the public. As far as solar technology is concerned, the most important aspect is that advertising about energy-efficient measures and practices and advertising required by NECPA's utility RCS program is not covered by the advertising standard. Utilities may publicize the energy-saving properties of solar systems and collect the publication cost from utility customers. Therefore, utilities should disseminate information about such available energy savings more widely than if shareholders and owners were bearing the costs.

\subsubsection{The Right to Intervene}

The Secretary of Energy is authorized to intervene in any state regulatory proceeding concerning gas utility rates; however, this intervention must be limited to advocacy of policies that promote the purposes of Title III [233]. He is also authorized to intervene in nonregulated utility rate proceedings on the same basis [234]. This right to intervene may help solar technology and solar system users if it results in the promotion of fair rates and more efficient use of gas utility facilities and resources.

\subsubsection{Proposals for Gas Conservation}

The public may participate in studies and proposals that the Energy Secretary must prepare for Congress [235]. The proposals must encourage natural gas conservation and equitable gas rate structures [236]. Public contribution will allow consideration of solar industry and solar user interests before the Secretary formulates his proposals concerning equitable gas rates. While these proposals would probably outline acceptable rate structures without public participation, it is reassuring that solar interests may be represented in the development of the gas rate structure recommendations.

\subsubsection{The Secretary's Report}

The Secretary must report annually to Congress any suggestions he may have for carrying out the purposes of Title III through federal action [237]. This requirement will help keep Congress informed of Title II's effect on gas conservation, efficient gas utility capital use, and equitable gas rate structures. Congress may then choose to adopt any of the Secretary's suggestions. The requirement provides a means of modifying Title III's provisions in order to achieve Congress' purposes. Inasmuch as attainment of those goals benefits solar energy users and technologies, the reporting requirement may also increase the probability that the goals will be met. 


\subsection{TITLE IV-SMALL HYDROELECTRIC POWER PROJECTS}

\subsubsection{The DOE Program}

This title establishes a DOE program to assist municipalities, electric cooperatives, industrial development agencies, and other interested organizations and persons in developing hydroelectric power projects of $15,000 \mathrm{~kW}$ or less at existing dam sites [238]. The Secretary may make loans for up to $90 \%$ of the cost of studying the practicability of hydroelectric projects at specific sites, and the cost of applying for necessary licenses for such projects [239]. Congress authorized $\$ 10$ million a year for the period from 1978 through 1980 for loans made pursuant to this provision [240]. The loans must be repaid within 10 years [24l]. The Secretary may also make loans up to $75 \%$ of the cost of any licensed small hydroelectric power project that will use an existing dam and not harm the surrounding environment [242]. Congress has authorized $\$ 100$ million for each year from $19 \overline{7} 8$ through 1980 for the purpose of making such loans [243], which must be repaid within 30 years [244]. In granting loans, the Secretary must select projects that will supply information on the technical and economic feasibility of small hydroelectric power production [245]. This information should be valuable. Section 403(c) directs assisted project operators to supply project information requested by the Secretary, and requires the Secretary to make such information available to the public. The data that results may be used to assess the practicability of small hydroelectric power projects.

\subsubsection{Simpler Licensing Process for Hydroelectric Projects}

Title IV also mandates the creation of a program to expedite licensing of small hydroelectric power projects planned for existing dam sites [246]. A simple, rapid licensing process will undoubtedly increase the rate at which projects are undertaken. Hydroelectric power technologies will benefit directly from Title IV. Other solar energy technologies and solar energy users will benefit indirectly from Title IV, because more small hydroelectric power facilities will be available. Solar energy that cannot he used immediately for other purposes may be used to pump water into impoundments. If hydroelectric power generating facilities are available at such dams, the stored water can later be used to generate electrical energy.

\subsection{TITLE V}

Title V covers crude oil transportation systems and will not have a direct effect on solar technologies.

\subsection{TTLE VI}

The first section mandates that the Secretary of Energy study the effects of federal laws on the rates established by state-operated electric utilities. He must then report his findings to Congress [247]. This requirement may have some effect on solar technologies and solar users, if (as a result of the study findings) federal action is taken to achieve more equitable electric rates for solar users.

The Secretary is authorized to cooperate with the Canadian Government in establishing transmission facilities for the seasonal exchange of electric power if such arrangement 
would result in more efficient use of electric utility capital and resources, conservation of electric energy, and equitable electric utility rates [248]. Cooperation based on such findings would affect solar technologies and solar users in two ways. First, if cooperation reduces the need for utility capital investment, rates for solar technology manufacturers and users will be lower. Second, lower utility rates would provide less incentive for conversion to solar energy systems because the available energy cost savings would not be as large.

\subsection{CONCLUSION}

PURPA should have a substantial, positive effect on the commercialization of certain solar technologies. Cogenerators that use a form of solar technology such as biomass, waste, or other renewable energy sources as their primary energy source will benefit from the act. PURPA will greatly promote cogeneration through its provisions on interconnection, wheeling, and equitable utility rates.

Small power producers, such as WECS owners, will also receive encouragement from PURPA. Utilities must now provide backup service, a market for the power produced by cogenerators and small power producers, and the use of transmission facilities. The national goal of nonrenewable energy conservation will be promoted because available backup service, markets, and transmission systems will convince consumers that cogeneration and small power production are worthwhile.

Hydroelectric technologies will also gain substantially from PURPA. The DOE program should prompt investigation and installation of hydroelectric facilities. Other solar technologies will profit indirectly from the DOE hydroelectric program. Additional hydroelectric power facilities result in increased storage facilities for the excess energy produced by various solar technologies. 
SER눙 


\section{SECTION 5.0}

\section{THE POWERPLANT AND INDUSTRIAL FUEL USE ACT}

\subsection{INTRODUCTION}

PIF UA [249] was intended to reduce the importation of petroleum and to promote the use of coal and other indigenous energy resources [250], as well as synthetic gases derived from such sources, in furtherance of the national goal of energy self-sufficiency [251]. Congress found that the use of alternative fuels by electric power plants and major fuel burning installations [252] would lead to petroleum conservation and further the purposes of PIFUA [253]. The alternate fuels referred to in the act include biomass; municipal, industrial, and agricultural wastes; wood; and renewable and geothermal energy sources [254. Wood and municipal solid wastes (MSW) already play an important role in supplying energy for steam production.

The act deals with the fuel usage of electric power plants and major fuel burning installations. Title I contains general provisions, definitions, and a statement of the purposes of the act.

Title II establishes gas and petroleum use prohibitions for new facilities and provides exemptions from those restrictions. The first prohibition is that new electric power plants must not use natural gas or petroleum as their primary energy source [255]. The second prohibition states that no new electric power plant may be built unless it is designed to use coal or an alternate fuel as a primary energy source. Wind energy systems, solar thermal systems, and biomass may be economically and technologically feasible for utility applications within five years [256]. In areas that lack coal transportation facilities, solar technologies may be the least expensive available primary energy source. Title II also prohibits petroleum and natural gas use by new, major fuel burning installations [257]. Installations whose construction or acquisition began after 10 Oct. 78, are considered "new" [258]. If construction or acquisition began between $20 \mathrm{Apr} .77$ and 10 Oct. 78, the installations may be categorized as new, if the Secretary finds that such an installation could meet Title II's prohibition without major financial or operating capacity losocs.

Title II lists numerous exemptions, both temporary and permanent, from the restrictions it has enforced. There will be many cases in which immediate enforcement of the prohibitions would lead to great hardship. For example, should fuel burning facilities be forced to shut down completely if their operators cannot immediately obtain an adequate and reliable supply of coal or an alternate fuel? The exemptions are not so extensive that they render the prohibitions meaningless, and may directly encourage solar energy equipment installations in power plants and major fuel burning facilities. Exclusion may be allowed because of a lack of reliable coal supplies or an alternate energy source, site characteristics that make the use of alternate fuels infeasible, or poor air quality that makes the burning of gas or petroleum necessary in order to meet air quality standards. Facilities that use a mixture of coal or an alternate energy source, petroleum, or natural gas may benefit from such immunity.

Title III deals with existing electric power plants and major fuel burning installations. It provides that natural gas may not be used as a primary energy source in a power plant after 1 Jan. 90. Existing power plants that used natural gas for their primary energy source in 1977 may use an amount equal to the yearly average used in the period between 
1974 and 1976 [259], in any year up to 1990. Title III gives the Secretary of Energy the authority to prohibit the use of petroleum or natural gas by existing, major fuel burning installations if he finds that the installation could use coal or an alternate fuel at an acceptable cost [260]. Title III also provides many exemptions. For instance, a permanent exemption is provided for electric power plants using fuel mixtures that contain synthetic fuels derived from. municipal or agricultural wastes, if such facilities promote the use of technologies to use renewable energy sources [261].

Title IV covers other prohibitions, such as those dealing with the use of gases derived from wastes to replace natural gas in outdoor lighting. Title IV also mandates conservation of gas and petroleum by federal agencies and persons assisted by federal agencies, resulting in the use of solar equipment to supply energy. Finally, Title IV provides licenses that permit electric power plants to use petroleum as a primary energy source, if the Secretary of Energy finds that the facility cannot meet clean air standards unless it uses pelroleum.

Title V provides electric utilities with an option: they may chose to comply with PIF UA's requirements on a system-wide basis, rather than a facility-by-facility basis. It should have little effect on solar technology.

Title VI authorizes financial assistance to areas of energy development and power plants for the purpose of installing air pollution equipment and does not affect solar technology.

Title VII covers the administration and enforcement of PIFUA. It mandates reports and studies and prescribes administrative procedures and judicial review of challenged administrative decisions. It also provides for civil and criminal penalties. Certain sections may affect solar technologies, and will be discussed in Section 5.8.

Title VIII contains miscellaneous provisions, none of which affect solar technologies.

Title IX sets the effective date of the act 180 days after its enactment.

PIF UA should have a dramatic effect on the use of certain types of solar energy systems. Electric power plants may soon utilize WECS, biomass, and solar thermal electric systems as their primary energy sources. Photovoltaic systems that may be economically feasible for utility applications by the mid- to late $1980 \mathrm{~s}$, may also be installed in utilities as a result of PIF UA.

\subsection{NEW FACIITIES, TTT,R II}

\subsubsection{New Eleetric Power Plant Prohibitions}

New electric power plants must be designed to use coal or an alternate fuel as their primary energy source [262] and must not burn natural gas or petroleum [263]. Power plants in areas without railroad facilities to transport coal may be designed to utilize some form of solar energy (heat, wind, biomass, or falling water) as their primary source. While solar energy cannot (economically or technically) supply the energy necessary to run every size of power plant in every location, it is an economic energy source for certain power plants. Because most forms of solar energy (such as solar thermal and wind) require no transportation, it will of ten be less expensive to rely on solar energy for power plant operation at locations lacking rail transportation facilities. Hydroelectric power 
plants built at dam sites will also be more economic than coal-fueled power plants. Municipal power plants can be designed to take advantage of methane produced for municipal waste, if such methane costs less than a comparable supply of coal.

\subsubsection{Eleetric Power Plant Temporary Exemptions}

Petitioners seeking temporary exemptions must establish that electric power to assure reliable service is not available at a reasonable cost within a reasonable distance.

Power plants may be permitted to use natural gas or petroleum for a period up to 10 years [264], if the Secretary of Energy finds that no ot her reliable supply of energy is available at a cost comparable to the price of imported petroleum [265]. Current Solar Energy Research Institute (SERI) studies indicate that solar thermal applications will become economic for some electric power plants when petroleum costs a utility $\$ 20$ a barrel [266]. Benchmark Crude sold for $\$ 18$ a barrel on the world market during the week ending 3 Aug. 79, according to the weekly Petroleum Status Report published 3 Aug. 79 [267]. With \$1.50-1.80 transportation cost added to that figure, the landed benchmark crude price is very close to $\$ 20$. Where solar energy is reliable, this exemption may soon be unavailable because solar energy will be obtainable at a cost comparable to the price of imported petroleum.

The Secretary may grant an exemption up to five years for a site-related inability to use an energy source other than petroleum or natural gas [268]. Site limitations include a lack of transportation space or facilities to use alternative fuels [269]. Of course, all power plants lack the facilities to use solar energy until they install them. However, the Joint Explanatory Statement issued by the House and Senate PIFUA conferees emphasizes that physical site limitations that could not be overcome despite good faith efforts may be the only basis of a temporary exemption under PIFUA $\$ 211(\mathrm{a})(2)[270]$. Power plant owners or managers may choose the type of alternative primary energy source they will use [271], and must use one unless they qualify for an exemption [272]. Because of the variety of solar technologies, each with different physical requirements, power plants may be forced to use solar energy systems even when they could qualify for an exemption from the mandatory use of coal. WECS, unlike coal, do not require a fuel transportation system, space for fuel storage, or space for pollution control equipment. Where the average wind velocity is able to supply adequate energy for a WECS, a power plant may have to install one rather than rely on natural gas or petroleum as its primary energy source.

Power plants may receive an exemption up to five years if their operators prove that applicable environmental standards can be met only if gas or petroleum remains the primary fuel [273]. While it is likely that the installation of solar energy power plants will damage the ecosystem in environmentally delicate areas, the operation of such plants should have minimal environmental impacts. The construction of any type of power plant will adversely affect environmentally delicate areas, and it is difficult to imagine many situations in which a power plant using natural gas or petroleum would be less environmentally damaging than one that utilizes some form of solar energy.

A 10-yr (or less) exemption from the prohibitions may also be granted when the operator of a power plant can cstablish that the plant will use a synthetic fuel at the end of the exemption period [274]. Methane derived from biomass is a synthetic fuel and may be used by some municipal utilities after their temporary exemptions have ended. This temporary immunity will allnw them to continue using petroleum or natural gas until they 
have developed or obtained an adequate and reliable supply of methane. Thus, it is likely that more power plants will use methane as their primary energy source than if the prohibition had been strictly enforced for all new power plants.

The Secretary of Energy may also grant up to a 5-yr exemption based upon public interest, if such an exemption would be consistent with the purposes of the act [275]. This provision was probably included in order to give the Secretary some flexibility in unforeseen situations.

\subsubsection{Permanent Exemptions}

Title II also provides for a number of permanent exemptions, The unavailability of an adequate and reliable supply of fuel or an alternate fuel during the first 10 years of operation is yrounds for an exemption [276]. The Secretary may also grant an exemption if he is convinced that the use of importen petroleum as a primary encrgy source during the useful lifetime of the plant would be significantly cheaper than the use of any other energy source [277]. In making such a determination, the costs of facilities to transport and.use alternate fuels must be included [278]. This cost inclusion may frequently lead to a determination that coal would be more expensive than imported petroleum. However, solar energy systems should become more competitive with imported petroleum as oil prices rise and mass production and improved production techniques reduce solar costs. A SERI study has found that when petroleum costs utilities $\$ 20$ a barrel and comprises about $60 \%$ of their primary energy sources, construction of some solar thermal facilities will be economical [279].

Site limitations, such as inadequate storage space or an insufficient water supply, may justify a permanent exemption [280]. A site limitation that might render solar energy use impracticable is a wet climate with a low average wind speed. Environmental requirements [281] or insufficient capital [282] may also justify noncompliance with the prohlbitions.

Power plant operators may obtain permanent exemptions if they establish that they cannot, despite good faith efforts, afford to finance construction and use coal or an alternate energy source. Permission to use petroleum or natural gas may then be obtained, or a facility that is not designed to use coal or an alternate energy source may be constructed. A.coal-fired plant expected to begin commercial operation in 1980 costs $\$ 675$ per $\mathrm{kW}$ of capacity. Oil and gas plants expected to begin operations in the same year cost between $\$ 335$ and $\$ 440$ per $\mathrm{kW}$ of capacity [283]. Solar power plants are estimated to cost between $\$ 1,100$ [284] and $\$ 1,400$ per $\mathrm{kW}$ of capacity [285]. This exemption, because of the significant difference in costs per $\mathrm{kW}$ of capacity, may rcsult in a number of new petroleum or natural gas fueled plants, especially where coal transportation or storage facilities are unavailable and the choice is between a solar, petroleum, or natural gas powered facility.

Electric power plants may use petroleum or natural gas as their primary energy source if their operators can establish that use of another fuel would be impractical because of state or local requirements, and that no other acceptable site is available for construction [286]. Solar energy proponents should investigate state and local regulations and work to change any regulation that would make a solar energy power plant impractical.

Cogeneration plants may receive a permanent exemption if the Secretary is convinced that the advantages of cogeneration would be lost if petroleum or natural gas was not 
used as the primary energy source [287]. Cogeneration using heat that is normally wasted during electricity generation is considered a solar technology when the primary fuel is renewable. If the cogenerator burned wood, methane gas, or a waste, it would be considered a solar energy cogenerator. The inclusion of a permanent exemption for natural gas or petroleum burning cogenerators obviously will not benefit solar technology.

Power plants using or intending to use a mixture of gas or petroleum and some alternate fuel are eligible for a permanent exemption. They must use no more gas or petroleum than is necessary to maintain reliable operation and adequate fuel efficiency [288]. This exemption may induce the designers and operators of some plants to use solar energy sources (such as methane from biomass) in situations where the use of a solar energy source alone would be unsatisfactory.

Power plant operators who can establish that reliability of service will be impaired without natural gas or petroleum use may receive an exemption [289]. Power plants that are to be used only to meet peak power demands [290] may use petroleum and natural gas if the appropriate air pollution control administrator certifies (to the Secretary of Energy) that the use of any other available fuel would result in unacceptable air quality [291]. Intermediate load power plants [292] may receive an exemption under similar circumstances. The petitioner must also show that no adequate site is available for such a plant, and that the plant will be able to use a synthetic fuel as its primary energy source in the future. The Secretary must periodically review intermediate load power plant exemptions and terminate them when a synthetic fuel is available for use as the primary energy source [293].

The requirement that intermediate laad power plants be built with the capacity to burn an alternate fuel makes it possible for power plants to burn methane or some other renewable fuel in the future. The exemption review provision insures that synthetic fuels will be used as soon as they are available. In the near term, the solar energy synthetic fuel that should be most affected by this provision is methane gas. Small- to mediumsized municipal utilities should increasingly use methane gas. This provision should encourage municipalities and stockyard operators to invest in methane production facilities by creating markets for methane gas.

\subsubsection{New Major Puel Burning Installation Prohibitions}

New major fuel buming boiler installations may not use natural gas or petroleum as their primary energy source [294]. Certain nonboiler installations [295] are also barred from using natural gas, petroleum, or both [296]. Biomass, solar thermal energy, and WECS can be expected to supply the primary energy for many new fuel burning installations.

Installations are eligible for temporary and permanent exemptions that are similar to those available to electric power plants. The exemptions are necessary and will not thwart Congress' attempts to conserve nonrenewable resources and reduce U.S. dependence on imported energy sources. Some of the temporary exemptions should increase the number of future solar energy powered installations, by allowing operators to rely on natural gas or petroleum while developing economic solar energy systems or supplies. 


\subsubsection{Temporary Installation Exemptions}

Installations, like power plants, may receive an exemption up to 10 years upon establishing the lack of a reliable, adequate, and reasonably priced supply of an alternate fuel [297]. A 5-yr exemption is available if a petitioner convinces the Secretary that site limitations make the use of an alternate fuel impossible [298]. If the use of an alternate fuel would lead to air pollution standard violations, an installation may use petroleum or natural gas for up to five years [299]. As with power plants, it is unlikely that site limitations or environmental requirements will justify temporary exemptions in areas where an adequate, reliable, and reasonably priced source of solar energy is available.

Installations that will use synthetic fuels in the future may receive an exemption up to 10 years [300]. If that synthetic fuel will be methane prodiren frnm hinmass, numerous installations can be built with methane-burning capacity even if an adequate supply of methane will not be available for several years.

'The Secretary may allow an installation to burn petroleum or natural gas if he finds such permission to be in the public interest [301]. He may also grant an exemption up to five years so that an installation with the capacity to burn no more than $300 \mathrm{M} \mathrm{Btu} / \mathrm{hr}$ may burn petroleum. To qualify, the petitioner must establish that the installation will use some other energy source for at least $75 \%$ of its fuel heat input rate after the exemption expires [302]. This provision allows installations to be built with the capacity to use solar energy fuels before such fuels are available.

\subsubsection{Permanent Installation Rxemptions}

Permanent exemptions may be granted because of a lack of alternate fuel supplies, site limitations, environmental requirements, or a lack of adequate capita] [3n3]. The requirements for qualification are nearly the same as those for power plants. An installation may receive a permanent exemption due to state or local requirements without establishing the lack of a satisfactory alternate site [304]. Major fuel burning installations may qualify for exemptions based on their use or planned use of a mixture of petroleum or natural gas and a synthetic fuel [305]. The Secretary may not set the percentage of petroleum or natural gas at less than $25 \%$. Installations may also qualify for permanent exemptions by establishing that only burning natural gas or petroleum can meet process requirements or assure adequate quality control [306]. Finally, installations that must burn natural gas or petroleum in order to meet scheduled equipment outages can qualify for permanent exemptions [307]. Most of these permanent exemptions should have no effect on solar technologies. They allow the burning of petroleum or natural gas where such fuels are necessary. It can be assumed that if such exemptions were not permitted, the facilities that needed them would simply not be built. The exemption for installations that will burn a mixture of petroleum or natural gas and a synthetic fuel should effect solar technology. Installations that could not rely on solar energy alone will be able to supplement their use of methane with natural gas or petroleum. The amount of methane burned in installations will thus be increased by the availability of this exemption. 


\subsection{EXISTING FACIIMTES, TIMLE III}

\subsubsection{Power Plant Prohibitions}

Title III prohibits the use of natural gas by existing electric power plants after 1 Jan. 90, and in some circumstances, before that date. If a power plant used natural gas as its primary energy source at any time during 1977, it may burn gas in an amount equal to the yearly average of the amount it consumed between 1974 and 1976. If it began normal operations after 1 Jan. 74 and burned gas at some point during 1977, it may burn an amount equal to the yearly average burned during its first two calendar years of operation [308]. The use of petroleum or natural gas may also be restricted if an existing power plant has or had the capability of using another primary energy source. The Secretary of Energy may also prohibit the use of natural gas or petroleum if it is found that a plant could burn some other fuel without major construction modifications or substantial reductions in its rated capacity. In either case, the use of an alternate primary energy source must be financially feasible [309]. The Secretary may also set a maximum ratio of natural gas or petroleum to an alternate fuel for plants if a mixed fuel is found technically and financially feasible [310].

These provisions will probably have some effect on the use of solar energy sources by existing power plants. There will be instances in which a power plant may be prohibited from burning natural gas or petroleum and will install solar thermal devices instead. This will become economically reaspnable, for instance, when petroleum costs the plant $\$ 20$ a barrel, heliostats cost $\$ 100 / \mathrm{m}^{2}$, and transportation facilities for coal are not available. Prohibiting the use of more than a certain percentage of natural gas or petroleum in a fuel mixture containing a synthetic fuel may become reasonable when municipal waste methane plants make an adequate supply of competitively priced methane available to municipal power plants.

\subsubsection{Installation Prohibitions}

Title III also gives the Secretary the authority to prohibit existing, major fuel burning installations from using petroleum or natural gas as their primary energy sources when it is found that an alternate fuel could be used without substantial physical modifications or a substantial reduction in rated capacity. The use of an alternate fuel must be financially practicable [311]. The Secretary may prescribe a ratio, which must be more than 1:3 of natural gas or petroleum to some synthetic fuel, for use as the primary energy source at existing installations if the use of such a mixture is determined technically and financially feasible [312]. The Secretary's authority with regard to fuel burning installations is similar to the authority he has concerning electric power plants, and should have the same sorts of effects on the use of solar energy systems.

\subsubsection{Temporary Exemptions}

The Title III prohibitions are followed by a number of exemptions, many of which are the same as those in Title II. Both power plants and installations may receive an exemption because of the lack of an adequate, reliable, and reasonably priced supply of an alternate fuel. Site limitations or environmental requirements [313], the planned use of a synthetic fuel [314], and exemptions that would be in the public interest [315] justify temporary exemptions. 
A temporary exemption may be granted to a power plant or installation if the petitioner establishes that the facility will adopt an innovative technology for the use of an alternate fuel upon expiration of the exemption [316]. This provision may eventually lead more existing facilities to convert to the use of solar energy because it will allow them more time to develop economic means of using solar energy. It should also encourage the development of new solar energy technologies by permitting power plant and fuel burning installation operators to use natural gas or petroleum for another 10 years af ter a prohibition on the use of such fuels has taken effect [317].

Units that will be retired within five years from the effective date of a prohibition (and in the case of natural gas burners, by 1994 even if that date is more than five years from the effective date) are eligible for an exemption for the remainder of their operating days [318]. There are two other temporary exemptions available to existing power plants. The first is available to pcak-load power plants. They may, with the Secretary's consent, burn natural gas until 1994 or petroleum for five years after the date upon which petroleum use was prohibited [319]. The second is available to all power plants. They may burn natural gas or petroleum (for the same time periods) upon a demonstration that the reliability of their service would othewise be impaired [320].

\subsubsection{Permanent Exemptions}

The lack of an alternate fuel supply, site limitations, or environmental, state, or local iequirements may be the basis for permanent exemptions [321]. Cogeneration facilities can qualify by demonstrating that unless natural gas or petroleum is used as the primary fuel, the advantages of cogeneration will be negated [322]. Facilities that will use a fuel mixture containing no more petroleum or natural gas than is needed to maintain reliable operation and adequate fuel efficiency are eligible for a permanent exemption [323]. Existing electric power plants may use a greater percentage of natural gas if the Secretary finds that it will be mixed with synthetic fuels derived from muniripal or agricultural wastes. The purpose of this provision is to encourage the use of technologies to utilize renewable energy sources [324], and allows the Secretary to promote the development and adoption of solar energy technologies by making them more technically feasible.

Peak load power plants are eligible for permanent exemptions if denial of the exemption would lead to impaired reliability of service, and the modifications needed in order to comply with the prohibitions are either technically or financially not feasible [325]. Interm ediate load power plants may burn petroleum only af ter a petitioner has made the same showing that was required to qualify new intermediate load plants for an exemption under Title II [326].

Base load power plants [327] that burn fuel at less than 250 million Btu/hr and that could not be converted to coal burning facilities without substantial modifications and a large reduction in power generating capacity, may receive permanent exemptions to burn natural gas [328]. In areas in which a coal-burning power plant would result in or conwibute to air pollution in excess of national ambient air quality standards, a power plant may burn liquified natural gas [329]. These last two exemptions provide for the use of natural gas where coal burning would be unacceptable, without regard to the possibility of using solar energy sources. The Committee Report explains that the Senate version of PIFUA did not cover existing power plants that consumed less than 250 million Btu/hr, while the House version did. Perhaps because of the difference between the bills, a less 
stringent standard was set for exemptions [330]. The report does not explain why power plants may burn petroleum or natural gas if burning coal would lead to ambient air pollution standards violations, without regard to the possibility of using solar energy as the primary energy source.

Existing installations that have received natural gas by pipeline from Canada since before $21 \mathrm{Apr} .77$ may receive a permanent exemption if a petitioner can establish that the pipeline also serves residential or commercial users who consume less than 50 mcf $\left(1000 \mathrm{ft}^{3}\right)$ on peak days, and whose service would be jeopardized if service to the installation were to cease [33l]. Obviously, such installations are not solar conversion candidates.

Finally, if product or process requirements necessitate the use of petroleum or natural gas, or if such fuels are needed in order to meet scheduled equipment outages, a permanent exemption is available [332]. Such exemptions should have little effect on solar technology commercialization. If petroleum or. natural gas is absolutely necessary for plant operation, solar energy would not be used as the primary energy source under any circumstances. Without the exemptions, such installations would presumably have to close.

\subsection{THML IV}

Title IV contains miscellaneous prohibitions, few of which should have much effect on solar energy use. There is a ban on natural gas use for decorative outdoor lighting [333]. Title IV also authorizes the President to exempt any federal power plant or major fuel burning installation from PIFUA prohibitions where national military interests demand such an exemption [334]. Federal agencies that extend financial assistance must require compliance with the PIFUA provisions by assisted parties [335]. This section provides an effective means of enforcing PIFUA's provisions and should have a positive effect on solar energy use when it leads to enforcement of provisions concerning solar energy.

Finally, there is a section that authorizes Secretary permission of an existing power plant to burn more petroleum than it burned in 1977. Such permission may only be granted when it is found that the plant must burn petroleum if it is to meet Clean Air Act [336] standards, or that reliable service will be impaired unless petroleum is burned as the primary energy source [337].

\subsection{TTHLE V}

Title V provides electric utilities with the option of complying with Title III on a systemwide rather than unit-by-unit basis. It should not have much effect on solar energy technologies or their consumers.

\subsection{THME VI}

The Secretary of Energy is authorized to make loans to owners and operators of existing power plants for the purpose of financing the purchase and installation of certified air 
pollution control devices at facilities that are being converted to coal burning plants. Air pollution control equipment is expensive and might have been a factor in decisions to convert to solar energy rather than coal. The availability of such loans may encourage some plant owners and operators to convert to coal rather than solar energy use.

\subsection{TITLE VII}

Title VII authorizes the Secretary to require owners or operators of power plants or major fuel burning installations to provide the needed information in order to implement PIF UA [338]. Such persons must submit annual reports in compliance with PIF UA's provisions [339]. The effect of the provisions on solar energy use will be indirect; they will simply ensure that the Secretary has information necessary to affect widespread compliance with the substantive provisions of the act.

Title VII also sets enforcement procedures. There are criminal penalties for willful violators of the act or any rule or order issued pursuant to the act [3401. There are rivil penalties up to $\$ 25,000$ for every day on which a person is in violation of the act, rules, or orders issued pursuant to it [341]. Injunctions may be issued against violators [342], and citizens may sue the Secretary or the head of any federal agency with a duty to perform under the act, if there is an alleged failure to perform [343]. With such a range of enforcement procedures, PIF UA should be implemented in most cases.

Solar energy will benefit because PIFUA's provisions will in some instances leave operators of power plants and major installations with no choice but to utilize some type of solar energy as their primary energy source.

\subsection{CONCLUSION}

PIFUA should result in some solar-powered, major fuel burning installations and electric power plants. Solar thermal utility and major installation applications will be especially common in areas that lack railroad transportation facilities. Methane gas produced from municipal solid waste or biomass may be the primary energy source of a number of municipal power plants. Major fuel burning installations that are located near feedlots in the Midwest may take advantage of feedlot waste to create methane gas. In windy areas, especially those in which power plants and major fuel burners cannot use coal, WECS may supply the necessary power. Many solar applications might become so economically attractive that even without PIFUA's prohibitions, power plants and major installations would rely on solar energy. However, PIFUA should result in an earlier increase in use of solar technologies for these applications. 


\section{SBCTION 6.0}

\section{THE NATURAL GAS POLICY ACT OF 1978}

This act prescribes well-head price controls [344], extends federal control over intrastate natural gas prices, mandates the deregulation of some natural gas prices [345], and the regulation of gas prices for certain industrial fuel prices [346]. It will not have a direct effect on solar technology commercialization or solar energy system users. Because it will result in higher natural gas prices, it will have an indirect effect on solar technology commecialization: it will make solar systems economically competitive with energy systems designed to consume natural gas for certain applications.

Because NGPA's effect will be so indirect, a detailed discussion of the various provisions of the statute and how they relate to solar energy systems is not warranted. 


\section{SEPI}




\section{SECTION 7.0}

\section{CONCLUSION}

The National Energy Act will affect the use of many solar technologies. All types of residential solar equipment will be installed more frequently as a result of NECPA's RCS program. Solar domestic water heating systems are cost effective in more areas of the country than any other type of residential solar energy equipment, and should receive the greatest boost in sales as a result of the RCS program.

The ETA will also positively affect solar technology commercialization. Both homeowners and business owners (including industrial users) will install solar energy equipment because of the tax credits offered by ETA.

PURPA will affect residential and commercial users of solar energy equipment. The equitable utility rates and efficient utility resource use that PURPA promotes should result in significantly lower utility bills for solar energy equipment users. Lower utility bills should attract increasing numbers of solar energy users, and solar technology commercialization will proceed at a faster pace.

PIFUA will affect a different sector of the solar industries by promoting power plant and large industrial solar applications. Producers of large capacity solar energy systems should benefit significantly from PIF UA's implementation, in terms of increased product dem and.

The entire solar industry, except for passive system designers and builders, should experience greater product demand because of the National Energy Act. While certain parts of the act provide for product and workmanship standards, others will stimulate a market for solar energy systems without imposing any standards. The solar energy industry must establish its own product and workmanship quality controls, in order to maximize the opportunities for a greater share of the earlier energy system markets that the National Energy Act provides. 
S=PI数 


\section{SECTION 8.0}

\section{REFERENCES}

1. Pub. L. No. 95-621, 92 Stat. 3352.

2. Congressional Research Service, 96th Cong., lst Sess., The 95th Congress and Energy Policy Committee Print 1979.

3. National Energy Conservation Policy Act, Pub. L. No. 95-619, 92 Stat. 3206; Public Utilities Regulatory Policies Act, Pub. L. No. 95-617, 92 Stat. 3117; Powerplant and Industrial Fuel Use Act, Pub. L. No. 95-620, 92 Stat. 3289; Energy Tax Act, Publ. L. No. 95-618, 92 Stat. 3174; and Natural Gas Policy Act, Pub. L. No. 95-621, 92 Stat. 3352.

4. H.R. Rep. No. 541, 95th Cong., 2d. Sess., (1978) reprinted in (1978) U.S. Code Cong. \& Ad. News, 7677, 7677.

5. Id. 7678.

6. NECPA Title II, Part 1.

7. Id.

8. 44 Fed. Reg. 16546 at 16559 .

9. Id.

10. NECPA Title II, Parts 3 and 4.

11. NECPA Title III.

12. NECPA Title V.

13. ETA Titles I and III.

14. PURPA Titles I and III.

15. PURPA Title II.

16. PURPA Title IV.

17. PIFUA Titles II and IIT.

18. H.R. Rep. No. 496,95 th Cong. 2 d. Sess. 7, (1978) reprinted in 1978 U.S. Code Cong. and Ad. News 8043,8045 .

19. NECPA $\$ 102$.

20. See NECPA $\$ 210(4)$ where public utilities are defined to include persons, state agencies, and federal agencies engaged in the business of selling natural gas or electric energy, or both, to residential customers for use in residential buildings.

21. 44 Fed. Reg. 16546 at 16547 .

22. $\$ 210$ defines terms used in Title II. "Residential energy conservation measures" includes solar energy devices that are designed to conserve residential energy. Only devices that are warranted by their manufacturers to meet specified performance levels for at least 3 years are defined as such measures. This requirement should promote public acceptance of solar devices by ensuring that they are of adequate quality. The inclusion of solar devices in the definition of residential energy conservation measures is very important to the solar energy 
industries. It means that the services that must be offered by utilities will include information on and arrangements to install and finance solar devices.

23. 44 Fed. Reg. 16546 at 16552. (to be codified in 10 C.F.R. 456)

24. 44 Fed. Reg. 27200-27202.

25. NECPA \$ 219.

26. NECPA $\$ 219$.

27. 44 Fed. Reg. 16546 at 16550 .

28. 44 Fed. Reg. 16546 at 16588 .

29. Id. $\$ 215$.

30. NECPA, S 215; 44 Fed. Reg. 16546 at 16559.

31. NECPA 3213.

32. NECPÁA $\$ 213(\mathrm{a})(2)$.

33. 44 Fed. Reg. 16546 at 16595 and 16604 .

34. Solar Heating and Domestic Hot Water Systems 4930.2, 1977 Ed., U.S. Dept. of Housing and Urban Development.

35. 44 Fed. Reg. 16546 at 16604 .

36. Id.

37. 44 Fed. Reg. 16546 at 16597 (to be codified at 10 C.F.R. 456).

38. 44 Fed. Reg. 16546 at 16604 .

39. Id. at 16596.

40. Id.

41. Id. at 16597 .

42. Id. at 16558 .

43. 44. Fed. Reg. 16546 at 16596 .

44. 12 U.S.C. $\$ 1716$ et seq., 27 June 34, c. 847 , Title III, $\$ 301,48$ Stat. 1252 (1969).

45. 12. U.S.C. $\$ 1451$, (1957).

46. 12 U.S.C. $\$ 1701$ et seg. (1969).

47. 12 U.S.C. $\$ 1716$ et seq. (1969), Pub. L. No. 95-619, 92 Stat. $3228 \$ 242$.

4R. Id. NFCPA $\$ 244$.

49. That is the level equal the current average yield on outstanding interest-bearing obligations of comparable maturity than are part of the public debt. Id. $\$ 244$.

50. 12 U.S.C. 1451 et seq. (1957).

51. NECPA $\$ \$ 245,246$.

52. See 12 U.S.C. $\$ 1454$, (1957).

53. NECPA \$ 248.

54. Id. $\$ 224$. 
55. Id. $\ 248$.

56. Id. $\$ 251$.

57. 42 U.S.C. $\Im 6801$ (1977).

58. NECPA, Pub. L. No. 95-619, § 252, 92 Stat. 3206.

59. Telephone interview with Dave Engle, DOE 7-10-79.

60. NECPA, Pub. L. No. 95-619, $\$ 253,92$ Stat. 3206.

61. Id. $\$ 302$.

62. 44 Fed. Reg. 19340 at 19351 (to be codified at 10 C.F.R. 450),

63. NECPA, Pub. L. No. 95-619, \$302, 92 Stat. 3206.

64. (1978) U.S. Code Cong. and Ad. News 8116.

65. 42 U.S.C. $\$ 6201$, (1977).

66. NECPA, Pub. L. No. 95-619 $\$ 302,92$ Stat. 3206, EPCA $\$ 393,42$ U.S.C. $\$ 6201$ (1977).

67. 44 Fed. Reg. 19340 at 19352 (to be codified at 10 C.F.R. 450) for audit guidelines.

68. NECPA, Pub. L. No. 95-619, $\$ 302,92$ Stat. 3206.

69. NECPA $\$ 302$, EPCA $\$ 394(a)(5), 42$ U.S.C. $\$ 6201$ (1977).

70. NECPA $\$ 302$.

71. NECPA $\$ 302$, EPCA $\$ 395$ (b).

72. 44 Fed. Reg. 22940 at 22951 (to be codified at 10 C.F.R. 455).

73. NECPA $\$ 302$, EPCA $\$ 391$ (17).

74. 44 Fed. Reg. 22940 at 22949 (to be codified at I0 C.F.R. 455).

75. NECPA $\$ 302$, EPCA $\$ 396$ (d).

76. 44 Fed. Reg. 22940 at 22949.

77. NECPA $\$ 302$.

78. 44 Fed. Reg. 22940 at 22952 (to be codified at 10 C.F.K. 455 ).

79. Id.

80. NECPA $\$ 311$, EPCA $\$ 400$ ACT.

81. NECPA $\$ 310$ (b).

82. NECPA $\$ 311$, see 44 Fed. Reg. 22940 at 22949 (to be codified in 10 C.F.R. 455 ).

83. NECPA $\$ 311$.

84. 44 Fed. Reg. 22940 at 22949.

85. NECPA $\$ 523(a)(1)(B)$.

86. NECPA $\$ 545$ (b).

87. NECPA $\$ 521$.

88. 44 Fed. Reg. 19328, (to be codified at 10 C..F.R. 436).

89. NECPA $\$ 523$. 
90. NECPA $\$ 524$.

91. NECPA § 542.

92. NECPA $\$ 546$.

93. NECPA $\$ 545$.

94. 44 Fed. Reg. 25366, (to be codified at 10 C.F.R. 436).

95. Id. \$ 546 .

96. NECPA $\$ 547$ (c)(3).

97. Id. \$ 562 .

98. In. $\$ 564$.

99. Id. $\$ 565$.

100. 44 Fed. Reg. 21195 (to be codified at 10 C.F.R. 436).

101 . Id. $\$ 569$.

102. NECPA joint explanatory statement of the conference p. 124.

103. Id. at 27199 .

104. Id. at 27195.

105. Id. at 27199.

106. Energy Tax Act, Pub. L. No. 995-618, 92 Stat. 3174 (1978) (to be codified at 26 U.S.C. 44C).

107. Id. $\$ 301$.

108. Id. $\$ 101$.

109. Id.

110. Landis, J. The Impact of Income Tax.

111. "Laws on the Energy Crisis: Oil and Congress Don't Mix." 64 Calif. L. Rev. 1055 (1976); Fanin, P. "Solar Energy: Overcoming the Barriers." 23 Ariz. Bus. 8 (1976).

112. See Oil and Congress, note 110, at 1081. •

113. Hirshberg, A. "Public Policy for Solar Heating and Cooling." Bulletin of The Atomic Scientist. Vol. 32 (No. 8); Oct. 1976, at 39.

114. Roach, F.; et al. Prospects for Solar Energy: The Impact of the National Energy Plan. Los Alamos Scientific Laboratory. 1977, at 23. (Hereinafter cited as Prospects for Solar Energy.)

115. Rosene, M. "Here Comes the Sun." Venture. July 1979, at 57.

116. Prospects for Solar Energy, note 114, at 21.

117. Id.

118. Id. at 3.

119. Id.

120. Id. at 42 . 
121. Booz-Allen and Hamilton, Inc. The Effectiveness of Solar Energy Incentives at the State and Local Level. PB-263 37 , U.S. Fed. Energy Admin. 1976, at III-6.

122. Id.

123. Proposed Rules, 44 Fed. Reg. 923 at 929 (1979) (to be codified in 26 C.F.R. Part I and 26 C.F.R. Part 601)

124. Id.

125. Id. at 929,930 .

126. ETA $\$ 101$.

127. Id. $\$ 101$.

128. Id. $\$ 101$.

129. Hereinafter, all references, to the 'Secretary' refer to the Secretary of the Treasury, unless otherwise indicated

130. ETA $\$ 101$.

131. Id.

132. Id.

133. Id.

134. See generally Proposed Rules, 44 Fed. Reg. 923 (1979)

135. Id. at 29,927 .

136. Id. at 928.

137. Id.

138. Active solar systems are based upon the use of mechanically forced energy transfer, such as the use of fans or pumps to circulate solar-generated energy. Passive solar systems are based upon the use of conductive, convective, or radiant energy transfer. For example, the costs of roof ponds, roof collectors, freestanding thermal containers, and nonwindow glazings, may qualify for the credit if used to enhance the collection and storage of solar energy for later use in heating or cooling the residence.

139. Proposed Rules, 44 Fed. Reg. at 29, 925. (1979).

140. Hyatt, S. "Thermal Efficiency and Taxes: The Residential Energy Conservation Tax Credit." 14 Harv. J. of Legis. 305 (1977)

141. Id. at 927.

142. Proposed Rules 44 Fed. Reg. 927 (1979).

143. Congressional Record-Senate, 23 Aug. 78. S. 14106.

144. Id.

145. Id.

146. Id.

147. Overcoming the Barriers, note 142 , at 5 . 
148. Energy Tax Act $\$ 101,92$ Stat. 3176 (1978); Proposed Rules, 44 Fed. Reg. at 29, 926.

149. Lewis, H. "Regulations Governing the Energy Tax Credit." 1 Solar L. Rep. 18 (1979). (Hereinafter cited as Regulations.)

150. Domestic Policy Review of Solar Energy Intergration Group. Status Report on Solar Energy Domestic Policy Review. Public Review Copy. 25 Aug. 78, at IV.

151. Lewis, H. "Regulations Governing the Energy Tax Credit." 1 Solar L. Rep. 18 (1979).

152. Regulations, supra note 151 .

153. Id.

154. Id. at 29,930 .

155. IU.

156. Performance and quality standards are currently being developed and will be the subject of a separate notice of proposed rule making.

157. See Proposed Rules, 44 Fed. Reg. at 931. The term 'inexhaustible supply' is not clearly defined in the proposed rules. However, it appears that wood and biomass energy sources will not apply.

158. See Section 2.1.2 concerning Congressional objectives in commercializing solar technologies.

159. Energy Tax Act $\$ 301,92$ Stat. 3194, 26 U.S.C. 46 (1978).

160. The Effect of Government Incentives, supra note 38, at 1 .

161. Id.

162. Id. at 2.

163. Id. The regular business investment credit is $10 \%$ on qualifying expenditures made from 21 Jan. 75 to 31 Dec. 80 or $7 \%$ for expenditures made after 1 Jan. 81 .

164. Internal Revenue Service, Publication 572. Tax Information on Investment Credit. 1977, at 3. (Hereinaf ter cited as Tax Information.)

165. Energy Tax Act $\$ 301,92$ Stat. 3196, 26 U.S.C. 48 (1978).

166. Id.

167. Id. $\$ 301,92$ Stat. 3197,26 U.S.C. 46 (1978).

168. Tax Information, supra note 164 , at 4 .

169. See Energy T'ax Act, Pub. L. No. 95-618, 92 stat. 3174, $\$ 301$ for more detailed explanation of qualifying alternative energy property.

170. Energy Tax Act $\$ 301,92$ Stat. 3197,26 U.S.C. 46 (1978).

17 1. Id.

172. Id.

173. Id.

174. See Calif. Ch. 168, 1976 amended, Ch. 1082 (1977) and N.M. Ch. 12 s.s. 1975 amended Ch. 120 (1978). 
175. See Davies, D. "The Feasibility of Standardized Legal Definitions for Solar Terms." Golden, CO: SERI (to be published).

176. Proposed rules for the investment credit were still in preliminary unpublished form at the time of this writing. Performance and quality standards will not be issued until af ter the proposed rules.

177. Energy Tax Act, $\$ 301,92$ Stat. 3198, 26 U.S.C. 103 (1978).

178. Id. generally.

179. Id. $\$ 301,92$ Stat. 3199,26 U.S.C. 48 (1978).

180. Id. at 5 .

181. Energy Tax Act $\$ 301,92$ Stat. 3199, 26 U.S.C. 31, 38, 39, 6201, 6401 (1978).

182. Tax Information, supra note 164 at 6 .

183. President Carter's Energy Program, supra note 9, No. 2, at 4.

184. Domestic Policy Review, supra note 150 , at 10.

185. Energy Tax Act $\$ 301,92$ Stat. 3194, 26 U.S.C. 46 (1978).

186. The Effect of Government Incentives, supra note 38, at 11 .

187. President Carter's Energy Program, supra note 9, No. 2, at 3.

188. Pub. L. No. 95-617, 92 Stat. 3117 (1978).

189. PURPA $\$ 2$.

190. PURPA $\$ 111$

191. PURPA Title II.

192. DOE defines small hydroelectric facilities as those with generating capacity of as $15,000 \mathrm{~kW}$ or less. PURPA $\$ 408$.

193. "Persons" includes state or federal agencies.

194. PURPA $\$ 101$.

195. PURPA $\$ 111(d)(3)$

196. PURPA $\$ 111(d)(4)$.

197. PURPA $\$ 111(d)(5)$.

198. PURPA $\$ 111(d)(6)$.

199. Feuerstein, R. J. "Utility Rates and Solar Commercialization." 1 Solar L. Rep. 305 (1979)

200. PURPA $\$ 201$.

201. PURPA $\$ 205$ (b).

202. PURPA $\$ 205$ (b).

203. PURPA $\$ 101$.

204. PURPA $\$ 111$.

205. PURPA $\$ 116$.

206. PURPA $\$ 121$.

207. PURPA $\$ 133$. 
208. 44 Fed. Reg. 31384 (1979) Final Rule.

209. 16 U.S.C. $\$ 191(a)$ et seq.

210. Small power production is that produced primarily from biomass waste or renewable resources by a plant with less than $80 \mathrm{MW}$ power production capacity, $\$ 201$.

211. PURPA \$ 202.

212. Id.

213. PURPA $\$ 203$.

214. PURPA \$ 202.

215. PURPA $\$ 204$ (a)

216. PURPA $\$ 204$ (a)

217. PURPA $\$ 204(a)$

218. PURPA $\$ 204$ (a)

219. PURPA $\$ 205(a)$

220. PURPA $\$ 205$ (a)

221. PURPA $\$ 205(\mathrm{~b})$.

222. PURPA $\$ 210(\mathrm{a})$, see 44 F.R. 38863 (1979)

223. PURPA $\$ 210(\mathrm{~b})$, see 44 F.R. at 38863 (1979)

224. These include the FPA, the Public Utility Holding Company Act, and state laws and regulations respecting rates or financial or organizational regulation.

225. PURPA \$210(e).

226. PURPA $5210(c)$.

227. PURPA \$ 213.

228. PURPA \$ 301(a).

220. PURPA \$ 303(b).

230. PURPA $\$ 303(b)$.

231. PURPA $\$ 304$.

232. PURPA $\$ 303$.

233. PURPA $\$ 305(a)$.

234. PURPA $\$ 305(\mathrm{c})$.

235. PURPA $\$ 306(d)$.

236. PURPA $\$ 306(\mathrm{~b})$.

237. PURPA $\$ 309$.

238. PURPA $\$ 401$.

239. PURPA $\$ 402$.

240. PURPA $\$ 407$. 
241. PURPA $\$ 404$.

242. PURPA $\$ 403$.

243. PURPA $\$ 407$.

244. PURPA $\$ 404$.

245 PURPA $\$ 403(\mathrm{~b})$.

246. PURPA $\$ 405$.

247. PURPA $\$ 601(a)$.

248. PURPA $\$ 602$.

249. Pub. L. No. 95-620, 92 Stat. 3289 (1978).

250. Hereinaf ter referred to as alternate fuels.

251. PIFUA § 102.

252. Facilities designed to consume fuel at a rate of at least 100 million $B t u / h r$.

253. PIFUA $\$ 102(a)$.

254. PIFUA $\$ 103(6)$.

255. Such fuels may be used "for unit ignition, startup testing, flame stabilization, and control uses." PIFUA $\$ 103(a)(15)(A)$.

256. Hollan, J.; et al. Annual Review of Energy. Palo Alto, CA: Annual Reviews, Inc.; Vol. $3 ; 1978$, at 496 .

257. Stationary units with boilers, gas turbines, or internal combustion engines capable of consuming at least 100 million $\mathrm{Btu} / \mathrm{hr}$ or 250 million Btu/hr if there is more than one unit at the site, are major fuel burning installations.

258. PIFUA $\$ 103(11)(A)$.

259. PIFUA $\$ 301(\mathrm{a})(3)$.

260. PIFUA $\$ 302$.

261. PIFUA $\$ 312(d)(3)$.

262. PIFUA $\& 201$ (b).

263. PIFUA $\$ 201(a)$.

264. PIFUA $\$ 211(\mathrm{e})(2)$.

265. PIFUA $\$ 211(a)(1)$.

266. Doane, J.; et al. A Government Role in Solar Thermal Repowering: A Draft Report of the Repowering Strategy Analysis. SERI/TP-51-340. Golden, CO: Solar Energy Research Institute; Aug. 1979.

267. DOE-EPC-0018.

268. PIFUA $\$ 211(\mathrm{a})(3)$.

269. PIFUA $\$ 103(a)(16)$.

270. PIFUA Joint Explanatory Statement of the Committee of Conference, $\$ 103$ at 71.

271. 1d. at 72 . 
272. PIFUA $\$ 201$.

273. PIFUA \$ $211(\mathrm{a})(3)$.

274. PIFUA $\$ 211(\mathrm{~b})$.

275. PIFUA $\$ 211$ (c).

276. PIFUA $\$ 212(\mathrm{a})(1)(\mathrm{A})(1)$

277. PIFUA \& 212(a)(I)(A)(ii).

278. Id.

279. See note 283.

280. PITUA § $212(\mathrm{a})(\mathrm{l})(\mathrm{B})$.

281. PIFUA \$ $212(\mathrm{a})(1)(\mathrm{C})$.

282. HIFUA $\$ 212(\mathrm{a})(\mathrm{L})(\mathrm{i})$.

283. Budwani, R. N. "Fossil-Fired Power Plants: What It Takes to Get Them Built." 82 Power Engineering 37 (1978), Fig. 2.

284. "SOLCHEM-A Chemical Approach to Solar Energy." 3 Sun-Up. 2 (1979).

285. McKrae, A.; Dudass, J., eds. The Energy Source Book. Germantown, MA: 1977, at 396 .

286. PIFUA $\$ 212(\mathrm{~b})(1)(2)$.

287. PIFUA $\$ 212(\mathrm{c})$.

288. PIFUA $\$ 212(d)$.

289. PIFŪA \$ 212 (f).

290. Peak load power plants generate no more electricity in a 12-month period than they would produce if generating at full capacity for 1500 hours. PIFUA \$103(a)(18).

291. PIFUA $\$ 212(\mathrm{~g})$.

292. Power plants that produce no more electricity in any year than they would if run at full capacity for 3500 hours PIFUA $\$ 103(a)(18)$.

293. PIFUA $\$ 212(h)$.

294. PIFUA $\$ 202$.

295. PIFUA $\$ 202$. Such instaliations are to be identified by rule issued by the Secretary. The proposed rule had not been published by 15 Aug. 79 .

296. PIFUA \$ 202(b).

297. PIFUA \$ $211(\mathrm{a})(1)$.

298. PIFUA $\$ 211(\mathrm{a})(2)$.

299. PIFUA $\$ 211(a)(3)$.

300. PIFUA \$ $211(\mathrm{~b})$.

301. PIFUA $\$ 211(\mathrm{c})$.

302. PIFUA $\$ 211(\mathrm{~d})$.

303. PIFUA \$ 212(a). 
304. PIFUA $\$ 212(\mathrm{~b})(\mathrm{z})$.

305. PIFUA $\$ 212(d)$.

306. PIFUA $\$ 212(i)$.

307. PIFUA $\$ 212(j)$.

308. PIFUA $\$ 301$.

309. PIFUA \$ 301.

310. PIFUA $\$ 301$.

311.' PIFUA $\$ 302(a)$.

312. PIFUA $\$ 302(b)$.

313. PIFUA $\$ 311(a)$.

314. PIFUA $\$ 311(\mathrm{~b})$.

315.' PIFUA $\$ 311$ (e).

316. PIFUA $\$ 311$ (c).

317. PIFUA $\$ 311(\mathrm{~h})$.

318. PIFUA $\$ 311$ (d).

319. PIFUA $\$ 311(f)$.

320. PIFUA $\$ 311(\mathrm{~g})$.

321. PIFUA $\$ 312(\mathrm{a})(\mathrm{b})$.

- 322. PIFUA \$ 312(c).

323. PIFUA \$ 312(d).

324. PIFUA $\$ 312$ (d)(3).

325. PIFUA $\$ 312(\mathrm{f})$.

326. PIFUA $\$ 312$ (g).

327. Those which generate more $\mathrm{kW}$ hours of electricity than would be produced were the plant to operate at full capacity for 3500 hours. PIFUA $\$ 103(\mathrm{a})(18)(\mathrm{c})$.

328. PIFUA $\$ 312(\mathrm{~h})$.

329. PIFUA $\$ 312(\mathrm{i})$.

330. PIFUA Joint Explanatory Statement of the Committee of Conference, $\$ 312$.

331. PIFUA $\$ 312(j)$, mef $=1000 \mathrm{ft}^{3}$ of natural gas, PIFUA $\$ 103(\mathrm{a})(27)$.

332. PIFUA $\$ 312(\mathrm{k}),(1)$.

333. PIFUA $\$ 402$. There are, of course, exceptions: lights of historical importance; memorial lights; commercial lights that are to replace similar lights and that are traditional and in conformity with the architecture; industrial or distribution company lights that are to replace similar lights, are necessary for public safety, and are the only economically feasible sort of outdoor lighting.

334. PIFUA $\$ 403$.

335. PIFUA $\$ 403(b)$. 
336. 42 U.S.C. $\$ 7410$.

337. PIFUA \$ 405.

338. PIFUA \$ 711 .

339. PIFUA § 712.

340. PIFUA \$ 722.

341. PIFUA $\$ 723$.

342. PIFUA $\$ 724$.

343. PIFUA $\$ 725$.

344. NGPA Title I, Subtitle A.

315. NGPA Titlc I; Subtitlc B.

346. NGPA Title II. 


\begin{tabular}{|c|c|c|}
\hline $\begin{array}{c}\text { Document Control } \\
\text { Page }\end{array}$ & \begin{tabular}{|c|c}
$\begin{array}{r}\text { 1. SERI Report No. } \\
\text { TR-434-424 }\end{array}$ & 2. NTIS Accession No \\
\end{tabular} & 3. Recipient's Accession No. \\
\hline \multirow{2}{*}{\multicolumn{2}{|c|}{$\begin{array}{l}\text { 4. Title and Subtitle } \\
\text { The National Energy Act Statutes and Solar Energy }\end{array}$}} & $\begin{array}{r}\text { 5. Publication Date } \\
\text { February } 1980 \\
\end{array}$ \\
\hline & & 6. \\
\hline \multicolumn{2}{|c|}{$\begin{array}{l}\text { 7. Author(s) } \\
\text { Judy Howard } \\
\end{array}$} & 8. Periorming Organization Rept. No. \\
\hline \multirow{2}{*}{\multicolumn{2}{|c|}{$\begin{array}{l}\text { 9. Performing Organization Name and Address } \\
\text { Solar Energy Research Institute } \\
1617 \text { Cole Boulevard } \\
\text { Golden, Co }\end{array}$}} & $\begin{array}{l}\text { 10. Project/Task/Work Unit No. } \\
6721.40\end{array}$ \\
\hline & & $\begin{array}{l}\text { 11. Contract (C) or Grant (G) No. } \\
\text { (C) } \\
\text { (G) }\end{array}$ \\
\hline \multirow{2}{*}{\multicolumn{2}{|c|}{ 12. Sponsoring Organization Name and Address }} & $\begin{array}{l}\text { 13. Type of Report \& Period Covered } \\
\text { Technical Report }\end{array}$ \\
\hline & & 14. \\
\hline \multicolumn{3}{|l|}{ 15. Supplementary Notes } \\
\hline \multicolumn{3}{|c|}{$\begin{array}{l}\text { 16. Abstract (Limit: } 200 \text { words) The National Energy Act of } 1978 \text { contains many provisions that } \\
\text { will significantly affect solar technology commercialization and solar energy users. } \\
\text { Four of the five statutes that comprise the National Energy Act deserve close } \\
\text { attention. The National Energy Conservation Policy Act will promote residential solal } \\
\text { installations. The Energy Tax Act will accelerate both residential and commercial } \\
\text { solar system applications. The Public Utilities Regulatory Policies Act promotes } \\
\text { efficient use of utility resources as well as decentralized power production. And, } \\
\text { the Power Plan and Industrial Fuel Use Act places severe restricitons on future } \\
\text { burning of petroleum and natural gas, which should lead some operators to build or } \\
\text { convert to solar energy systems. Each-of the preceding acts are considered in } \\
\text { separate sections of this report. Federal regulations issued pursuant to the various } \\
\text { provisions are also identified and discussed, and some of the problems with the } \\
\text { provisions and regulations are noted. }\end{array}$} \\
\hline \multirow{2}{*}{\multicolumn{3}{|c|}{$\begin{array}{l}\text { a. Descriptors Energy ; Legislation; Solar Energy ; Commercialization ; Regulations ; } \\
\text { Residential Sector ; Installations ; Public Utilities ; Petroleum; Natural Gas } \\
\text { b.ldentifiers/Open-Ended Terms National Energy Act of } 1978 \text {; National Energy Conservation } \\
\text { Policy Act ; Energy Tax Act; Public Utility Regulatory Policies Act ; Natural Gas } \\
\text { Policy Acy of } 1978 \\
\text { c.UC Categaries } \\
\quad \text {. . }\end{array}$}} \\
\hline & & \\
\hline \multicolumn{3}{|c|}{$\begin{array}{l}\text { 18. Availability Statoment } \\
\text { National Technical Information Service }\end{array}$} \\
\hline \multicolumn{3}{|c|}{$\begin{array}{l}\text { U. S. Department of Commerce } \\
5285 \text { Port Royal Rnar } \\
\text { Springfield Virginia } 22161\end{array}$} \\
\hline
\end{tabular}

